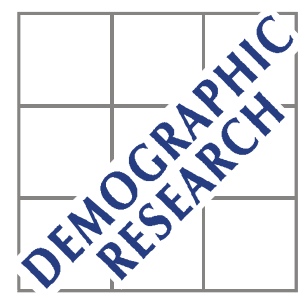

Demographic Research a free, expedited, online journal of peer-reviewed research and commentary in the population sciences published by the Max Planck Institute for Demographic Research Doberaner Strasse 114 · D-18057 Rostock · GERMANY www.demographic-research.org

DEMOGRAPHIC RESEARCH

VOLUME 1, ARTICLE 4

PUBLISHED 2 SEPTEMBER 1999

www.demographic-research.org/Volumes/Vol1/4/

DOI: $10.4054 /$ DemRes.1999.1.4

\title{
Data Resources for Biodemographic Studies on Familial Clustering of Human Longevity
}

\author{
Natalia Gavrilova \\ Leonid Gavrilov
}

(C) 1999 Max-Planck-Gesellschaft. 


\title{
Data Resources for Biodemographic Studies on Familial Clustering of Human Longevity
}

\author{
Dr. Natalia S. Gavrilova, Ph.D.
}

Dr. Leonid A. Gavrilov, Ph.D.

Center on Aging

NORC/University of Chicago

E-mail: nsgavril@midway.uchicago.edu 


\title{
Data Resources for Biodemographic Studies on Familial Clustering of Human Longevity
}

\begin{abstract}
The main cause that hampered many previous biodemographic studies of human longevity is the lack of appropriate data. At the same time, many existing data resources (millions of genealogical records) are under-utilized, because their very existence is not widely known, let alone the quality and scientific value of these data sets are not yet validated. The purpose of this work is to review the data resources that could be used in familial studies of human longevity. This is an extended and supplemented version of the previous study made by the authors upon the request of the National Institute on Aging (1998 NIH Professional Service Contract). The review describes: (1) data resources developed for biodemographic studies, (2) data collected in the projects on historical demography, (3) data resources for long lived individuals and their families, (4) publicly available computerized genealogical data resources, (5) published genealogical and family history data. The review also contains the description of databases developed by the participants of the Research Workshops "Genes, Genealogies, and Longevity" organized by the Max Planck Institute for Demographic Research.
\end{abstract}

\section{Introduction}

In contrast to the remarkable progress in the genetics of yeast and nematode aging, little is known about genes that control human longevity. What is behind the records of extreme human longevity: just a lucky chance, favorable environment, or "good" genes? How to resolve the apparent controversy between strong familial clustering of human longevity, and poor resemblance in life span among blood relatives? What is the nature of the genetic component for such a complex quantitative trait as human longevity: special "longevity assurance genes" or just an individual variation in the burden of deleterious mutations? These fundamental problems remain to be unresolved, and the major obstacle for their solution is the lack of appropriate data.

The idea of this review on data resources and the understanding of its significance came to us as a result of long scientific discussions held at two International Research Workshops "Genes, Genealogies, and Longevity" (Louvain-la-Neuve, Belgium, October, 1998 and Rostock, Germany, May, 1999). These two workshops sponsored by the MaxPlanck-Institute for Demographic Research (Rostock, Germany) with the active participation of its Director, Dr. James Vaupel, has revealed many extremely interesting and bold scientific ideas on familial longevity, ... that cannot be tested now because of the lack of appropriate data!

The importance of the search for the new large data resources on familial clustering of longevity was also confirmed in our discussions with the participants of the Gordon 
Research Conferences on the Biology of Aging (Ventura, USA, January 1997, and Il Ciocco, Italy, May 1998), Meetings of the Gerontological Society of America (Philadelphia, November 1998), Population Association of America (Chicago, April 1998, and New York, March 1999) and the American Aging Association (Seattle, June 1999). As a result of the discussions following our presentations [68-71, 73, 74], it became quite clear, that further advancement in understanding the mechanisms of familial aggregation of longevity crucially depends on the development of new publicly available databases with large amounts of reliable data.

\subsection{Illustrative example: The hopes and disappointments with data on British aristocracy}

In 1997, we found a computerized historical genealogical database for about 33,000 British aristocrats (distributed by a rather obscure British company, S\&N Genealogy Supplies), that we initially believed could be a solution to the data problem. We have shared this information with our colleagues, and it was successfully used by Westendorp and Kirkwood [176] in their provocative study of the trade-off between human longevity and fertility, published by Nature with an acknowledgments of our efforts "for identifying the database" (see [176], p.746). The database became quite famous, but our further data quality control has revealed that this data set is extremely incomplete and for this reason, unfortunately, can NOT be a solution to the data problem [61].

First, the incompleteness of the database on British aristocracy is evident from an extremely biased sex ratio, indicating severe underreporting for women. The British database contains records for 19,380 males but for only 13,667 females, corresponding to the sex ratio of 1.42 [61]. The sex ratio in complete, high quality genealogies is close to the sex ratio at birth [101], which for Caucasian populations generally falls between 102 and 107 males per 100 females [101, 169].

Second (and even more important), in most cases there are no birth dates for women in this database, which makes the calculation of their life span impossible. Although 13,667 females are mentioned in the British database, the life span could be calculated in 2,441 cases only (see [176], Table 2 at p.745). In fact, this problem with British aristocratic women was first noticed by Karl Pearson a century ago [19, 20]. He studied the British Peerage data and had to exclude women from his consideration for the following reason: "The limitation to the male line was enforced upon us partly by the practice of tracing pedigrees only through the male line, partly by the habitual reticence as to the age of women, even at death, observed by the compilers of peerages and family histories" ([20], pp.50-51).

Thus, although the reasons for the incompleteness of the British database may sound rather funny (reticence to indicate the age of the British ladies), the scientific consequences of such data incompleteness are quite serious - this British database unfortunately can NOT be used in the scientific analysis in its present form.

Thus, this example demonstrates the need for systematic work for careful screening, collection and evaluation of various data resources, in order to select the most appropriate data sets. This review is the first step in this direction. 
The review also describes the results and findings of our previous feasibility study made upon the request of the National Institute on Aging and summarized in the form of the 35-page report submitted to NIA [60].

In this work, we have made a pilot search for prospective data resources related to familial aggregation of longevity that could be used in biodemographic studies of human longevity.

The world-wide search for the data resources was made in the following directions:

- Computerized products available on the international market (genealogical databases);

- Published family history data that could be recommended for use after computerization;

- Data resources developed for research purposes by other investigators;

- Special data sets on long-living people and centenarians in particular.

The search was made through Internet search engines, reviews of scientific publications and direct mail requests. The Inventory of Data Resources was developed and these resources were characterized with regard to their strengths and weaknesses for research purposes. A conclusion was made that millions of familial longevity records are available now for researchers and that the potential of existing data resources was understated and, as a result of that, the data resources were underused. However, further, deeper review and analysis of the Data Resources would be desirable in order to characterize their applicability for scientific research and to facilitate their use for scientific analysis.

\subsection{The content of this review}

This review consists of the following 5 sections:

Section 2 Data resources developed for biodemographic studies of longevity.

Section 3 Databases created for the studies in historical demography.

Section 4 Data resources for long-lived persons and their families.

Section 5 Computerized genealogical data (products available on the international market).

Section 6 Published genealogical and family history data (that could be recommended for their use after computerization).

The authors would appreciate any comments and suggestions to improve the completeness and quality of this review.

\section{Data resources developed for biodemographic studies}

Several data sets were collected directly for the purpose of studies of familial resemblance in human longevity and estimation of heritability of human life span. These 
data sets deserve to be made available for further studies of familial clustering of human longevity.

\subsection{Data on Finnish and Swedish middle class and noble families}

Data comprising 12,768 cases were collected from various published Finnish and Swedish nobility and middle-class genealogies by Dr. Eva Jalavisto from the University of Helsinki (Finland) in 1951. This study was supported by Finnish Cultural Foundation ("Suomen Kulttuurirahasto"). The results of data analysis were published [91], but the data were not used later. We have made an attempt to contact Dr. Jalavisto requesting her database and have found out that unfortunately she died in 1966 . We plan to contact the colleagues of Dr. Jalavisto (Dr. P.C. Holmberg in particular) at the Department of Physiology, University of Helsinki in order to find out the destiny of this data collection.

\subsection{French data on village of Arthez d'Asson}

This data set is the reconstruction of families from 1744-1975 based on the parish registers and civil registers (5196 births, 1538 marriages, 4365 deaths) for the village of Arthez d'Asson situated in the Ouzom Valley in Bearn (Department of Pyrenees Atlantiques). The data were collected and analyzed by Dr. Jean-Pierre Bocquet-Appel (Laboratoire d'Informatique pour les Sciences del'Homme, Centre National de la Recherche Scientifique, Musee de l'Homme, 17 place du Trocadero, 75116, Paris, France) and Dr. Lucienne Jakobi (CRA, Musee de l'Homme, F-75116, Paris, France). They have records for 542 paternal grandfathers (maximum life span of 98 years), 542 records for maternal grandfathers (maximum life span of 92 years), 542 records for paternal grandmothers (maximum life span of 97 years) and 542 records for maternal grandmothers (maximum life span of 92 years). For parents they have 542 records for fathers (maximum life span of 98 years) and 542 records for mothers (maximum life span of 102 years). For children they have 674 records for sons (maximum life span 94 years) and 688 records for daughters (maximum life span 102 years). The brief description of their database is published [24-25].

\subsection{Hauge-Harvald Database on Elderly Danish Twins}

This database is a part of Odense Archive of Population Data on Aging dataset (Program Director - Dr. James W. Vaupel).

The Hauge-Harvald Database on Elderly Danish Twins consists of individual level data on twin pairs born in Denmark between 1870 and 1930. For each twin pair, date of birth and dates of death (if dead), sex, and zygosity are available. Data availability: All of the above data are available and will be sent to qualified researchers on request.

Contact address:

Cindy Owens, Program on Population, Policy, and Aging, Box 90245, Sanford Institute, Duke University, Durham, N.C. 27708-0245; ph: (919)-613-7321; fax: (919)-681-8288.

This database was used in many studies on human longevity [42, 43, 82, 118].

\subsection{Cambridge Group for the History of Population and Social Structure Research Projects}




\section{Data-Bases}

English sources allow the construction of large-scale, individual data-sets for demographic analysis of adult males from c1300 and for the general population from 1538. These fall into two groups: those with full reproductive histories from family reconstitutions or genealogies, and those for unlinked individuals.

For the general English population from 1538 - 1837 the researchers have family reconstitutions of 110,000 marriages in 26 communities. Prof. J. Knodel who has kindly provided the access to his family reconstitution study of 29,000 marriages in 14 German villages (1600-1950) [101]. Also, Dr. T.H. Hollingsworth has kindly allowed the researchers to use his descendant genealogy of the British Peerage from 1603 to 1959, which contains full life-histories for 28,000 individuals and partial information on their grand-children.

The unlinked individuals, suitable for mortality studies only, come from elite groups and include a medieval database containing about 750 land-holders and 750 monks. In addition, there are records for 14,000 Scottish church ministers (1530 - 1927) and we have access to data for 17,000 Members of Parliament (1500-1860), courtesy of the History of Parliament Trust.

\section{1st Project: Long-Run Changes in Adult Mortality}

Researcher: J. Oeppen

The major findings of this project are that, with the exception of two early epidemic periods, levels of adult survival were largely unchanged until c1700, when the modern rise begins. From this date, females follow a pattern of steady improvement shared by other European countries. For men of all social classes, this upward trend is checked by urbanisation and industrialisation in the first half of the nineteenth century. There is little evidence of differentials in life-expectancy by sex or social class before 1800, although there is a strong marital status effect. Only amongst women aged 65 to 85 does wealth seem to be an advantage.

2nd Project: Historical Bio-Demography

Researchers: J. Oeppen and R. Davies

Amongst the hypotheses being investigated, a number are of interest to analysts of longevity, and exploit the fact that most of the data is for periods with high exogenous stress over the life-course, and natural fertility. For example, it was found across all the data that the reproductive history of a woman has no influence on her survival after age 50, thus confirming a long-held view amongst demographers. It was also found that the difference in mortality in the reproductive years between single and married women in the Peerage is explained by the number of children born, multiplied by the risk of maternal mortality. However, the gap between men and women in these ages is too large to be explained by maternal-mortality alone. Before 1900, maternal mortality is higher for elite-group women than amongst the general population. See [128] for more information.

\subsection{Longevity studies on the Valserine database}




\section{Research team}

Cournil A, Legay J-M. Laboratoire de Biométrie-Génétique et Biologie des populations. UMR 5558, Université C. Bernard Lyon 1.

Brunet G, Bideau A. Centre d'études démographiques, Université Lumière, Lyon 3.

Current research projects

Patterns of inheritance of human longevity (in co-operation with F. Schächter)

Modelling of sex-linked survival traits (in co-operation with Tan Q. and Vaupel J.)

\section{Database}

Historical population database of the Valserine valley

\section{Short description of the database}

The Valserine register reconstructs the population of five villages located in a narrow valley of the French Jura mountains, near the Swiss frontier, $10 \mathrm{~km}$ west of Geneva. Although more than 4,000 inhabitants dwelt in this region at the beginning of the $19^{\text {th }}$ century, about 1,000 locals live there nowadays. The reconstruction of the population was carried out through the analysis of all parochial and civil registers available. Data about approximately 70,000 vital events such as birth, baptism, marriage, death, burial from 1680 to 1980 have been recorded into two computer files of the SYGAP software. One file contains 46,390 individual mentions, the other one contains 14,115 union mentions. Individuals of this database can be linked to each other through kinship networks. This database was implemented on the initiative of Bideau A, Brunet $\mathrm{G}$ and Plauchu $\mathrm{H}$ within the framework of a co-operation between historical demographers and geneticists aimed at studying the transmission of Rendu-Osler disease, a rare benign autosomal dominant vascular disorder.

From this database a set of familial biographies has been selected to study the relationships between life spans of parents and children. The main focus in the study was on late mortality, taking into account post-reproductive survival (above age 50) for both generations. The first step of the study was to test for the existence of a familial component of longevity. The results showed a non-negligible contribution of a familial component in the variability of life-span above age 50. The second step consists in detecting particular patterns of inheritance associated with specific factors. In other terms, the goal is to test the influence of particular factors on the magnitude of the "correlation" between parents' and children longevity. A strong sex-effect in the transmission of longevity has been identified suggesting the contribution of sex-linked genetic traits. These results have led the researchers to develop and fit survival models integrating sex-linked traits.

Studies on longevity are published in $[44,45]$. Valserine Database was also used in many other biodemographic studies $[21,49,50,83,141]$.

\subsection{Framingham Longevity Study}

Family patterns for age at death were examined in a 40 year follow-up of 5209 men and women (2900 deceased, 2309 living) in the Framingham Longevity Study [33].

\subsection{Database on Six New England Families}


13,656 records for members of 6 New England families (Bradford, Bulkeley, Cushman, Denison, Pardee, Waterman) born 1650-1874 were collected and analyzed to study the historical trend in resemblance between first-degree relatives for age at death [117]. The maximum recorded life span in this sample was 109 years (female born in $18^{\text {th }}$ century).

\subsection{The Utah Population Database}

The creation and development of the Utah Population Database (UPDB) became possible when early in the 1970s permission was provided to copy records which are maintained by the Genealogical Society of Utah (GSU), an organization operated by the Church of Jesus Christ of Latter-day Saints (LDS). As a religious mandate members of the LDS church have been encouraged to identify their ancestors [14]. The GSU, located in Salt Lake City, Utah, is the world's largest repository of genealogical records. Each family group sheet submitted to the GSU by the members of the LDS church represents data on three generations: a husband and wife, their children, and their parents. The core of the Utah Population Database is a set of genealogies with more than 1.2 million names linked together in familial structures. These genealogies were selected for those records where at least one family member was born or died in Utah or on the pioneer trail followed by the members of the LDS church as they migrated from the midwestern states to Utah [14].

The second major set of records is the Utah Cancer Registry that was initiated in 1952 in large hospitals and which became statewide in 1966. The Utah Cancer Registry is maintained as a separate database, but could be linked to genealogical data if necessary.

UPDB also includes 1880 census data for the state of Utah representing approximately 143,000 individuals.

Another set of data is a file of death certificates for the period 1934 through 1981 that was included into UPDB. Now the entry of birth certificates is also in progress.

The UPDP is in the process of continuous developing with input and linkage to genealogical data the $20^{\text {th }}$ century death certificates and birth certificates. Combining with census data, this database could provide a unique opportunity for longevity studies, since many variables (e.g., social status data from the census, causes of death from death certificates) could be taken into account in addition to the standard familial variables (birth order, life span of parents and spouses, parity, etc.) drawn from genealogies. For more information on the Utah Population Database see special publications $[11,12,14-$ $17,95,112,119,157]$.

The Utah Population Database was used in several studies on life span inheritance. In one study 20,682 familial longevity records for 9,719 families with twins and sibs were collected and analyzed by Dr. Grace Wyshak (Department of Preventive and Social Medicine, Harvard Medical School, Boston, MA) [182]. In another study an analysis of twin longevity on 2,242 sets of twins, extracted from the Mormon Genealogy Data Base (currently UPDB) was carried out by Dr. Dorit Carmelli [39-40].

\subsection{The Laredo Epidemiological Project}

The Laredo Epidemiology Project is a study of the patterns of degenerative disease, particularly cancer, in the families of Laredo, Texas. This mostly Mexican-American population is of manageable size and relatively culturally homogeneous. This project is based on the family reconstitution using parish records on births, deaths and marriages from all 12 Catholic parishes in Laredo, and also records from civil registries and the one 
hospital in Laredo [38, 173]. The genealogical history of Laredo was reconstituted by the grouping of 350,000 individual church and civil vital event records into multigenerational families, with record linkage based on matching names [38]. The Laredo population database was used in several studies of familial aggregation of chronic diseases $[38,174$, 175].

\subsection{Genealogical Data on European Royal and Noble Families}

One of the best sources of genealogical data available is the famous German edition of the "Genealogisches Handbuch des Adels" (Genealogical Yearbook of Nobility) - the most reliable and complete data source on European royal and nobility families [75-78]. This edition is known world-wide as 'Gotha Almanac' ('Old Gotha' published in Gotha in 1763-1944 [7], and 'New Gotha' published in Marburg since 1951 [75-78]). Data from the Gotha Almanach were often used in early biodemographic studies of fertility (see [85], pp. 199-224, for references), although later this important source of genealogical data has been undeservedly forgotten.

Each volume of the New Gotha Almanach contains about 2,000 genealogical records appropriate for analysis, with more than 100 volumes of this edition already published. Thus, more than 200,000 genealogical records are available from this data source. The high quality of information published in this edition is ensured by the fact that the primary information is drawn from the German Noble Archive (Deutsches Adelsarchiv). The Director of the German Noble Archive (Archivdirektor) is also the Editor of the New Gotha Almanach.

It was not until 1995 when the information form the "New Gotha" Almanachs has been partially computerized by the research team of Dr. Leonid A. Gavrilov and Dr. Natalia S. Gavrilova (Center on Aging, NORC and University of Chicago). By the end of 1998 the database contained information on over 20,000 adult persons (over 30 years) born in 1700-1900 with complete information on their parents (including birth and death dates) and spouses. The studies of longevity using this database demonstrated substantially non-linear sex-specific transmission of human longevity from parents to offspring $[66,67,71-74]$ and effects of parental age at reproduction on the survival of adult offspring $[57,58,65,68-70]$.

\subsection{The Database of Qing Nobility (China)}

This database has been developed by Dr. James Lee (California Institute for Technology) and his colleagues (Dr. Wang Feng and Dr. Cameron Campbell) using genealogies of the Qing dynasty (1640-1911). By the mid-twentieth century the Imperial Lineage in its entirety included almost 200,000 persons: 80,000 in the principal line, and 120,000 in collateral lines. Dr. James Lee and colleagues transcribed and organized vital records for more than 80,000 individuals from the principal imperial line (most of whom lived in Beijing) using data from the Chinese historical archives and the copy of principal-line genealogy available through the Genealogical Society of Utah. One of the advantages of this database is virtually complete registration of females, with a sex ratio of 109 for children born before the Opium War (1839-42), that is close to the sex ratio of birth of 105. After 1840, however, the quality of the data deteriorates significantly (a reflection of dynastic decline) $[106,107,170]$. 


\subsection{Wang Genealogical Database (China)}

Chinese genealogies were collected and analyzed for the purpose of mortality studies by Zhongwei Zhao. The main source in his study was the General Genealogy of Wang Clan or Wang genealogy of Chinese upper class families. The Wang genealogy covers a very long period of time - since 900 until 1800. The Chinese database contained records for about 30,000 individuals, although many records were incomplete [183]. Also, in most Chinese genealogies no individual records were made for women. The life expectancy of individuals in the database was very low for the entire historical period (e.g., about 30 years in 1700-1749 at age 30) even for these upper class families [183].

\subsection{Special populations}

Data on special religious sects are often used by epidemiologists and geneticists in their studies. These sects usually share a relatively uniform environment and have a rather unique life-style that isolates them from the general population. In addition to Mormon data (described earlier), Hutterite and Amish populations are well studied now.

\section{A. Hutterite Population}

The Hutterites are an Anabaptist sect that originated in Moravia in 1528. Between 1874 and 1877, approximately 900 members of the sect migrated from Russia to the United States to the area which is now South Dakota. The Hutterites represent a closed population with high levels of fertility and consanguinity. The group maintains a stable residence pattern and keeps extensive genealogical records that could be used in studies of familial aggregation of human longevity. Until recently Hutterite data were used in numerous studies of fertility and inheritance of genetic disorders including [86, 104, 127].

\section{B. The Old Order Amish Genealogy Database}

The unique genealogic registry of Lancaster County, Pennsylvania, Amish contains information on 8,163 marriages, dating back to the time of the pioneer migrants in the 1700s and spanning more than 10 generations. This database also represents closed population with high level of inbreeding. The individual records in this database, however, are heavily truncated and the total number of persons in the database is not very high [100]. An Old Order Amish genealogy database is maintained now at the Department of Epidemiology, Johns Hopkins University School of Hygiene and Public Health, Baltimore, Maryland. This database was used in the studies of consanguinity effects and infant mortality and other studies in genetic epidemiology $[3,51,98,100]$.

\section{Data Bases Created for the Studies in Historical Demography}

\subsection{The population of Quebec before 1800: Demography - History - Genealogy}


The population database of Quebec has been created and developed due to the Programme de recherche en démographie historique (PRDH) at Université de Montréal, for the semi-closed and homogeneous population of manageable size for which there is excellent documentation - the entire French-Canadian population who lived in the present territory of the Province of Quebec from its first permanent settlement in 1608 to the middle of the 19th century. So far the database covers the entire period of French rule, up to the year 1800 .

Thanks to a grant from the Quebec's Government Fonds de l'autoroute de l'information, the Programme de recherche en démographie historique (PRDH) at Université de Montréal, in collaboration with Gaétan Morin Éditeur, is making available on the Internet genealogical information on Quebec of the seventeenth and eighteenth centuries. This wealth of information, which has been gathered over thirty years, is organized into three sets:

1. A Repertory of Vital Events 1621-1799

2. A Genealogical Dictionary of Families 1621-1765

3. A Repertory of Marriages and Filial Relations 1621-1799

Individual and family biographies are constructed by linking individuals to their baptismal, marriage and burial certificates. Parental relations are based on identifying people in the marriage certificates. Linked in this essential way, the three sets available on the server are also linked directly by hyperlinks. Marriages in the Repertory of vital events are linked to the corresponding marriages in the Repertory of marriages and filial relations. Mentions of the principal individuals in certificates prior to 1766 are linked to their individual files in the Genealogical Dictionary. The dates and places of events births, marriages, deaths - in the Dictionary are linked to the corresponding certificates. Families are linked to marriages, and marriages to certificates. Within the Dictionary, parents are linked to their children, their parents, and their spouses. In short, you can "navigate" from an ancestor to his or her descendants, from a descendant to his or her ancestors, from a husband to his wife (or wives) and vice versa, from an event date to a corresponding certificate in the documents, and many other combinations.

This database was used in many studies of fertility and mortality in historical population $[22,41,46,49,50,124]$ including the study of a trade-off between early fecundity and longevity [105].

\subsection{Umeå Demographic Data Base}

The Demographic Data Base began as a temporary employment project in 1973 under the auspices of the National Archives of Sweden. The aim was to computerize parish registers to make them available for research. The irreplaceable historical records in the Archives were in urgent need of protection from further wear and tear. Database operations have increased in both range and extent, and are established today in three places; Umeå, Haparanda and Jörn. Since 1978 the Demographic Data Base is a special unit at the Umeå University and employs in all about 70 people.

POPUM, the population database, is a major information system. It deals with about 365,000 persons, about whom there are 1,644,000 entries in the sources. POPUM is a relational database. The tables contain the information from the 19th century parish 
registers. Most of the variables are taken directly from the sources, e.g. name, sex, date of birth and marriage details. A number of new variables are created, e.g. details concerning migration, trade/profession, marital status and housing. What is unique about the Demographic Data Base is its individual-based parish register material with its wealth of detail and high quality. The material is so consistently high class that it allows for the creation of an integrated information system where various source materials can be linked together.

The parish registers contain numerous references to each individual, the number usually depending on how long the person was resident in the parish. By linking together the separate references to someone, an integrated information system can be built up. Essential details on birth, marriage, childbirth and death are recorded, as are migrations between households, villages, parishes and even to foreign countries. Details concerning occupation/trade and, where relevant, taxable property ownership can establish social status, mobility and grades for reading ability and comprehension were entered in the registers.

Through the parish registers it is also possible to establish interpersonal relationships. Family relationships (parents, spouse and children) provide extensive genealogical material, and even more indirect relationships can be established grandparents, siblings and cousins, for instance. The information system facilitates the reconstruction of life-histories on the individual and the family level. There is thus every chance of being able to perform both longitudinal (e g course of life studies) and crosssectional analyses.

The primary materials computerized by the Demographic Data Base consist of entries on individuals in 19th-century parish registers: a) Catechetical lists; b) Ministerial lists of births, marriages and deaths; c) Migration lists.

The Centre for Population Studies (CPS) was formed on July 1, 1990, as an integral part of the Demographic Data Base (DDB). Its main objective is to develop research on the material computerized by the DDB, and to stimulate national and international research on the DDB material, where possible within a multi-disciplinary context. The CPS will seek to promote research by disciplines, such as sociology, demography, statistics, epidemiology and human genetics. An international Advisory Board for the CPS has been appointed, whose main role is to contribute to the further development of the DDB as an important international research centre. The Board advises the DDB management on research matters and functions as an ambassador for the DDB, and its products.

The CPS research policy is to promote new research based on the DDB database and to focus resources on important research fields. It will also promote the creation of a number of visiting research positions and scholarships at the CPS in order to encourage a wider use of the DDB research material. The research policy will be submitted to relevant political bodies and research councils. It provides the framework for the formulation of new research projects.

The Center for Population Studies has the following research priorities:

1. The Individual and Family Life Cycle

2. Population Genetics and Genetic Epidemiology

3. Social and Spatial Mobility 
The Umeå Demographic Database was used in several studies on historical demography including mortality and health studies $[35,111,162]$.

\subsection{BALSAC Population Register}

BALSAC Population Register is maintained at the Interuniversity Institute for Population Research (IREP) organized by the Université du Québec à Chicoutimi, McGill University, Université de Montréal and Université de Sherbrooke, Université Laval. Research activities of the Institute are concerned with the formation and evolution of Québec's regional populations (17th-20th centuries). Each of the three research programs deals with a specific dimension of population studies: physical and social reproduction (social sciences), biological characteristics (human genetics, epidemiology), and cultural dynamics (customs, rituals, regional identities). All of the projects call on the BALSAC population register. Developed from baptism, marriage, and death certificates, this register will eventually contain individual and family histories on virtually the entire population of Québec, from 1800 to the present. More information about BALSAC database could be found in the following publications: [28-32, 88, 140].

\subsection{The Genealogical Database on Nine New England Families}

These data come from nine published genealogies of New England families whose ancestors migrated from Old to New England before 1650, during The Great Migration. These genealogies follow persons of a particular surname whether they happened to live, and thus document the settlement of the American North from New England out to the Midwest, from 1650 to 1880 [96].

The records are most complete for men born several years before the books were published, making it possible for their deaths to be recorded in them. Therefore the researchers focus in what follows on the 3612 men descended in the male line born before 1840 (and who survived to age 20), 79\% of whose records end in death. In all, $72 \%$ moved from their natal towns during their lifetimes.

The genealogies used in this study trace the families forward in time from the first person with the surname to come to America. These genealogies are also the product of family reconstitution, carried out both by professional genealogists and by family members wishing to trace their ancestry back to the founder who brought their surname to America. These reconstitutions differ from those done from parish records, because the compilers have followed the descendants wherever they happened to go.

The researchers also added information from the 1850 and 1860 censuses that was not in the genealogies to the data base [96].

\subsection{The Union Army Project}

A large family history sample related to the "Union Army Project on early indicators of later work levels, disease \& death" was created on the basis of 23 American family histories [52-55, 143, 144]. The total sample comprises 49,419 individuals [143]. However, the majority of individuals were later eliminated from the data used for mortality analysis (probably because of data quality problems). Using this data set, Pope analyzed adult mortality in the United States in the 19th century and found that family histories appear to be quite representative of the related populations [143]. 


\section{Data resources for long-lived persons and their families}

One of the approaches to study of the familial aggregation of human longevity is to find long-lived persons (nonagenarians and centenarians, etc.) and then to collect information about their families for further scientific analysis. In this review the following investigators were identified who work in this research area and who might be contacted for the purpose of collecting more detailed information about their databases:

\subsection{Baltimore Longevity Study}

The Baltimore Longevity Study was initiated in 1922 by Raymond Pearl who collected data on the ancestry of nonagenarians [132]. This study was extended further by Professor Edmond Murphy at Johns Hopkins University and produced many new results important for understanding the mechanisms of human longevity $[1,2,81,122]$. This study was supported by grant GM-08944 and by grant 5-R01-CH00330 from the U.S. Public Health Service. Preliminary attempts to find these data from one of the participants of this Study (Dr. Helen Abbey) revealed that the archives were lost during relocations in the Johns Hopkins University. However, other participants of the Baltimore Longevity Study will eventually be contacted for the purpose of locating this unique source of information on familial longevity.

\subsection{Centenarian Studies in Europe}

\subsubsection{Familial studies of centenarians in France}

The largest survey of centenarians has been started in 1990 by the IPSEN Foundation in France that included medical examination of 756 persons (663 women and 93 men), about a quarter of the estimated total number of centenarians living in France [5, 6, 148]. Dr. Michel Allard, the head of the project, is actively collecting familial data on French centenarians over the whole country.

Drs. Robine and Allard [149] have studied the familial aggregation of longevity among the relatives of the longest-lived woman Jeanne Calment, who died in Arles, France on August 4, 1997, at the age of 122 years and 164 days. For the purpose of their study they have identified 62 immediate ancestors of Jeanne Calment corresponding to 5 generations (two parents, four grandparents, eight great-grandparents, 16 great-greatgrandparents, and 32 great-great-great-grandparents). Robine and Allard [149] were able to validate the lengths of life for 55 ancestors out of these 62 . They have found that the immediate ancestors of Jeanne Calment lived longer than the matched controls, especially on her paternal side. On the other hand, the parents of Jeanne Calment had lost two children in infancy before she was born, while her brother died at age of 97 [149]. Robine and Allard also collected genealogical data on familial longevity for the city of Arles where Jeanne Calment was born [148].

\subsubsection{The Italian Multicentric Study of Centenarians}

This study involves 21 University Centers and focuses on epidemiological and socioeconomic characteristics of centenarians. The investigation examined 382 randomly 
selected centenarians from a total 1162 centenarian subjects recorded by Italian census carried out on 31 December, 1993. The analysis included collection of family history data. Analysis of the data revealed that the centenarians had a family history of long life: the mean survival of centenarians' parents $(73 \pm 16.5$ years $)$, grandparents $(78.76 \pm 15.3$ years) and siblings $(70.71 \pm 25.3$ years $)$ was much higher than that of Italian population in 1950 (66 years). For the complete list of the participants see special publications [113, 163].

Recently the National Institute on Aging has been established in Italy (Director Dr. Claudio Franceschi). One of the scientific directions of this Institute is the study of Italian centenarians, including studies of familial clustering of longevity.

\subsubsection{Familial studies of centenarians in Belgium}

Data on Belgian centenarians and their families are being actively collected by Dr. Michel Poulain (Professor of the Center on Demographic Studies for Public Administration, GéDAP, Université Catholique de Louvain, Belgium), Dr. Dany Chambre and Michel Foulon. They have collected data on more than 5000 Belgian centenarians born in 1870-1897. Information on centenarians' genealogies is also collected using archive data and other sources [145].

\subsubsection{Swedish Centenarian Study}

These studies are carried out by Sven-Mårten Samuelsson, Bo Hagberg, Gillis Samuelsson, Betty Bauer Alfredson, Bertil Nordbeck at the Gerontology Research Centre, Lund, Sweden.

The purpose of this project, is to identify the medical, psychological and social qualities in the centenarians, to relate the centenarians characteristics to known aging models, to assess the different qualities contributing to the attainment of advanced age, to make interdisciplinary comparisons in cooperation with other international centenarian studies and to identify national and general aging determinants. Centenarians born 188791, who lived in southern Sweden were asked to participate in this multidisciplinary study $(\mathrm{N}=164)$. Of the survivors $(\mathrm{N}=143), 70$ percent agreed $(\mathrm{N}=100)$. The purpose was to describe the population from physical, social, and psychological points of view; to characterize centenarians with various health conditions and diverse degrees of autonomy and life satisfaction; and to identify factors at 100 years that predict future survival. Results: Eighty-two percent were women, 25 percent lived in their own home, 37 percent in old age homes, and 38 percent in nursing homes. Socioeconomic status showed a similar distribution compared to nationally representative data. Fifty-two percent managed activities of daily living with or without minor assistance. The incidence of severe diseases was low. Results suggested that centenarians are a special group genetically. A causal structure model emphasized body constitution, marital status, cognition and blood pressure as particularly important determinants for survival after 100 years [151].

\subsubsection{Centenarian Studies in Denmark}

\section{Research team}

Jeune B, Skytthe A, Vaupel JW, Olsen H, Andersen-Ranberg K 
Odense Universitet, Center for Helsetjenesteforskning og Socialpolitik (CHS).

\section{Current research projects}

- Nonagenarians and centenarians in Denmark. A clinical-epidemiological survey of a dynamic cohort.

- $\quad$ Lifespan and exceptional longevity.

\section{Data on long-lived persons kept at CHS:}

- the Danish Centenarian Register,

- $\quad$ The International Oldest-Old Database.

In these projects the demography of centenarians in Denmark in the period 1775-1995 were studied. The prevalence of centenarians in Denmark increased from about 1-2 pr. million in the last half of the 1800 s to about 80 pr. million in 1995 , especially among women since 1950 leading to a female/male-ratio of three to one. A total of 4292 centenarian deaths were found reported in different sources. The number of reported centenarian deaths was found to be much higher in the first half than in the last half of the 1800 s, especially among men and among $105+$ year-old: A thorough examination of 275 reported centenarian deaths on the Island of Funen from before 1900 indicates that this most plausibly was due to age-exaggeration and lack of validation of the reported ages before 1850 .

In another study the authors described morbidity and functional capacity of centenarians in the County of Funen. A total of 51 out of 58 centenarians on Funen born on May 1, 1894 or before participated. An interview could be carried out almost completely in $80.4 \%$ of the 51 participants, cognitive testing (MMSE) in $78.4 \%$ and physical performance test (PPT) in 49\%. Additional information on morbidity and activities of daily living (ADL) was collected on all 51 centenarians from family members, nursing staff, GP's, hospital registries and the National Cancer Registry. Almost 3/4 were women and 58.8\% were in an old people's home.

Studies on Danish centenarians are described in many publications $[9,10,23,79$, 92-94, 103, 130, 158, 179].

\subsubsection{Centenarian Study in Germany}

Centenarian studies in Germany are now conducted in the Max Planck Institute for Demographic Research (Founding and Executive Director - Professor James W. Vaupel, Ph.D.). The Max Planck Institute for Demographic Research was opened in October 1996 in Rostock to produce basic, scientific research on selected demographic questions. The focus of the studies is on questions that offer particularly promising opportunities for systematic, intensive investigation by collaborative teams of scholars. In cooperation with the venerable University of Rostock (established in 1419), the Institute also endeavors to advance the scientific discipline of demography.

The Institute is currently involved in numerous research projects on longevity being conducted by the Laboratory of Survival and Longevity to study the question of why some people die at 60 and others at 90 and what can be done about it. One of the research projects is devoted to the Centenarians and Supercentenarians. 
A focus on extreme cases is often a good way to gain research leverage at reasonable expense. Almost all theories fit empirical data under ordinary circumstances - otherwise the theories would not have been proposed. Hence to test theories, extreme cases provide crucial information. Because only a few people per hundred (e.g., in Western Europe and Japan) or per thousand (e.g., in China) survive from age 80 to age 100, centenarians are worth studying, perhaps in comparison with octogenarians and nonagenarians. Even in the most developed countries today only a few centenarians per thousand survive to age 110, so such supercentenarians represent the outer extremes of human existence. An international Supercentenarian Register (with DNA data as well as environmental, behavioral and health data) could provide precious information and will be established and developed in the Institute. The work on establishing such a Supercentenarian Register in the Institute is in progress now [168, $171,172]$.

\subsubsection{Centenarian Study in Finland}

The research team working at the Second Department of Medicine, University of Helsinki include Louhija J., Miettinen H.E., Kontula K., Tikkanen M.J., Miettinen T.A., Tilvis R.S.

In their study the common polymorphism of apolipoprotein E (E2, E3, and E4), apolipoprotein B Xba I polymorphism, and apolipoprotein C-III Sst I polymorphism was determined in almost all Finnish centenarians alive in $1991(\mathrm{n}=179 / 185)$. Plasma lipid and lipoprotein levels in different apolipoprotein genotypes were also measured [110, 160].

\subsection{Centenarian Studies in the United States}

Centenarian studies in the United States are rather active now and include: (1) Georgia Centenarian Study, (2) familial studies of centenarians in Iowa, (3) New England Centenarian Study Projects and (4) studies on familial aggregation of human longevity using Utah Population Database (described above).

\subsubsection{Georgia Centenarian Study}

The Georgia Centenarian Study formally began in 1988 with a four-year research grant from the National Institute of Mental Health. A supplementary grant was obtained a year later to implement a nutrition component in the study.

In this study eighty-eight participants in each of three cohorts were tested: cohorts born in the 1880s (centenarians), 1900s (80-89 year olds at the time of testing), and 1920s. These cohorts were selected on the basis of their experience of distinct historical events (i.e., the Great Depression and World War II) during their developing years. The ages of the centenarians were confirmed by relatives and one other source $\{$ e.g., family bible). Because the State of Georgia did not begin to compile formal birth records until the 1920s, it was not possible to verify the date of birth by formal means. Secondary government sources (e.g., social security) were also helpful in confirming an individual's age. 
The centenarians were recruited by referrals from a wide network of state (including the offices of the Governor and Secretary of State) and local agencies, churches, television and print media, and individuals contacted by the project staff. A full-time recruiter worked to track down referrals across the state of Georgia, obtain informed consent, perform preliminary screening, schedule participants and testers in different parts of the state, explain the study to family or relatives, debrief the participants and families, and keep track of the changing status of the participants (birthdays, health status and institutionalization, and funerals).

During the study information about longevity of siblings, parents, grandparents, and children was obtained. The information was verified by at least one other source to ensure its accuracy. Family longevity was used as an individual-difference variable to predict membership in age groups in our individual-difference model. Other information collected in this study included: Social and environmental support, Personality, Stress and coping, Life satisfaction and morale, Health, Mental health, Nutrition and dietary patterns, Intelligence and cognition, Reminiscence, Religiosity. This study has not revealed familial history of longevity among centenarians. For more information see the related publications $[114,142]$.

\subsubsection{Familial studies of centenarians in Iowa}

Large collection of data on long-lived persons in Iowa with attempts to collect information about their families was managed by Dr. Peter Martin (Human Development and Family Studies, Iowa State University, 209, CD Building, Ames, IA, 50011, USA). The data on Iowa long-lived persons including centenarians are kept in computerized form. Since Dr. Peter Martin is working now in Germany, the current status of the project could be requested from the Human Development and Family Studies Department of the Iowa State University.

\subsubsection{New England Centenarian Study Projects}

Based at Harvard Medical School and Beth Israel Deaconess Medical Center, the New England Centenarian Study's mission is to study centenarians who we believe carry the secrets to successful aging and how to delay or even escape diseases associated with aging. The underlying hypothesis of the study is that centenarians are a select cohort who have a history of aging relatively slowly and who have either markedly delayed or entirely escaped diseases normally associated with aging such as Alzheimer's disease, cancer, stroke and heart disease. The study is made up of 4 major components: (i) an ongoing population-based medical and demographic study of approximately all centenarians living within Boston and seven of its suburban communities

(ii) neuropsychological-neuropathological correlation, definition of what is "normal" versus what is disease among this group (iii) population genetics, discovering familial patterns relating to the phenotype of extreme longevity and (iv) molecular genetics, searching for both nuclear and mitochondrial longevity enabling genes using centenarian sibling-pairs, families highly clustered for extreme longevity and random centenarian subjects in conjunction with younger controls $[8,134-139,156]$.

\subsubsection{Studies of Familial Longevity Using Utah Population Database}


Familial data on long-lived persons are studied at the University of Utah, Salt Lake City, UT on the basis of Utah Population Database. There are two projects devoted to the studies of familial aggregation in human longevity and supported by the National Institute on Aging (PI - Dr. Richard Cawthon): the R03 project "Selection of families for genetic analyses of longevity" and the K01 project "Identification of genes contributing to human longevity".

The specific aims of these research projects are 1) To test the hypothesis that mitochondrial inheritance contributes to longevity, and 2) To develop criteria to select sib pairs suitable for genetic linkage studies of longevity. Both aims will be carried out by analyzing mortality and family relationship data in the Utah Population Database, a large genealogy containing records on approximately 1.2 million individuals from 170,000 families.

\subsection{Centenarian Studies in Asia}

\subsubsection{Centenarian Studies in Japan}

Centenarians in Japan consisted of number 4,152 persons. By prefecture, Tokyo had the most centenarians (383), followed by Okinawa (193) and Fukuoka (151) prefectures. Fukui had the least (24), followed by Akita (26) and Ishikawa (29) prefectures. The proportion of centenarians in Japan was 21.6 (per 100,000 populations) in 1990. By prefecture, the highest proportion lived in Okinawa (133.8), whereas the fewest were found in Akita (8.9) [129].

\section{a. Tokyo Centenarian Study}

Department of Psychiatry, Tokyo Metropolitan Institute of Gerontology.

A survey to investigate the psychiatric and physical characteristics of centenarians was conducted from 1987 to 1989 in the Tokyo metropolitan area with a team of psychiatrists and psychologists using a semi-structured interview form. In that period, out of 509 centenarians living in Tokyo, 294 persons and their caregivers $(57.8 \%)$ including the 65 institutionalized centenarians were examined. Two hundred and fifteen centenarians were not able to be interviewed due to various reasons. Out of 294 centenarians, 76 persons (25.9\%) were interviewed by telephone. Also out of these, $176(59.8 \%)$ were living with their son's or daughter's family. Ten male centenarians $(12.8 \%)$ were living with their wives, while no female was living with a spouse. Five men and four women were living alone [84]. Then this study was continued in 1994 and 1995 when information on 45 Japanese centenarians living in Tokyo metropolitan area during was collected [84].

\section{b. Study of Okinawan Centenarians}

In this study conducted by the Research Center of Comprehensive Medicine, School of Medicine, University of Ryukyus, Japan, 87 healthy Okinawan centenarians and 148 healthy Okinawan controls were examined since 1987 with HLA phenotyping and family history questionnaires. The mean age in centenarians was 101.6 years, and that of controls was 66.4. The age and the cause of death of 
the parents of the subjects were also inquired. Subjects whose parent's deaths were by suicide, homicide, accident, war or due to war trauma, were excluded and only those resulting from illness or natural causes were included. The relation between age of death of parents and HLA-DR types were studied. Compared to controls, DR1 was significantly increased in the centenarians $(p=0.036, R R 4.239)$, and DR8 was decreased $(p=0.012, R R=0.412)$. When the mean age of death of parents for each DR group and that of total was determined, the mean death age of those with DR9 was significantly lower than the mean of the total $(\mathrm{p}<0.05)$. Moreover, when the frequency rate of the DR types were compared with the parents' death age, that of DR9 decreased as the age of death increased. It was suggested that some loci of HLA-DR relate to longevity and some genetic protection against immunorelated diseases contributes to long-lived lineage [4, 126].

\section{c. Study of Centenarians in Nagoya City}

The purpose of this study (conducted by the Department of Internal Medicine, Nagoya City Kohseiin Geriatric Hospital, Japan) was to assess the background to the longevity of 36 centenarians in Nagoya city and to compare 14 institutionalized centenarians out of those 36 with 202 individuals in the 70-99 age group in a special nursing home, particularly with regard to blood chemistry and immunity tests. Authors conclude that the reasons for their social longevity in terms of profile appeared to be attention to eating habits, abstention from smoking and drinking, occupations with adequate exercise. The incidence of dementia was $65.6 \%$ among them [89].

\subsubsection{Centenarian Studies in China}

\section{a. Study of Centenarians in Beijing}

Studies of Chinese centenarians are developed by Dr. Zeng Yi and Dr. Wang Zenglian (Institute of Population Research, Peking University, Beijing 100871, China) in collaboration with Dr. J.W.Vaupel (Max Plank Institute for Demographic Research, Doberaner Strasse 114, D-18057 Rostock, Germany). Dr. Wang Zhenglian at PAA meeting (Chicago, 1998) has reported the results of her in-depth survey of the living arrangements, lifestyle and health status of 208 centenarians from Beijing, Chengdu and Hangzhou, China [172].

\section{b. Study of Centenarians in Shanghai}

This study was conducted by the Shanghai Institute of Geriatrics, Hua Dong Hospital, Shanghai, People's Republic of China.

One hundred and sixty centenarians were discovered and followed up for 7 years (1982-88) in Shanghai. The proportion of centenarians in the population was non-significantly greater in the urban than in the rural area and centenarians were in general increasing in both areas over the years. The factors promoting longevity were good medical care and benevolent attention from family members. 
Autopsy was performed in eight centenarians revealing the main causes of death as pneumonia and cancer [184].

\subsection{Centenarian Studies in the Former Soviet Union}

\subsubsection{Centenarian Studies in Azerbaijan}

Researchers from Azerbaijan have collected information on Azerbaijan centenarians: Chingiz Gasimov, Director of the Laboratory of Physiology and Longevity at the Physiological Institute, Ulduz Hashimov from the Institute of Physiology and Arif Abbasov, Director of the Institute of Archeology and Ethnology. These scientists look forward to continuing their studies and in doing joint research with international groups in the future as the study of longevity is a field ripe for contributions from many disciplines-biologists, anthropologists, psychologists, physiologists, demographers, ethnographers, and folklorists.

\subsubsection{Centenarian Studies in Russia}

Scientists from the Russian Institute of Public Health (Moscow), Dr. Victoria G. Semyonova and Galina N. Evdokushkina in collaboration with Dr. Leonid A.Gavrilov and Natalia S. Gavrilova (now in Chicago) have collected and computerized data on Russian nonagenarians and centenarians including information on their genealogies. Now they continue to collect these data in collaboration with the Historical and Genealogical Society in Moscow [62].

\section{Computerized Genealogical Data}

Development of Internet and user-friendly computer programs awoke a real boom in computerization of pedigree data by professional and non-professional genealogists. The process of computerization started in early 90s and now the number of computerized genealogies is being increased in geometrical progression. Most of such genealogies are kept as private collections or databases with restricted access (information could be disclosed to relatives only). We list below the sources of genealogical data available in public domain as well as data sold by commercial organizations and persons. Also, the most important collections of computerized genealogical data with restricted access are mentioned below.

Technical note. Although each particular genealogical software has its own data format, the genealogical data could be shared among other genealogists through the so-called GEDCOM format. GEDCOM stands for the GEnealogical Data COMmunication standard proposed by the Family History Department of The Church of Jesus Christ of Latter-day Saints, and adopted by many developers and users of genealogical software. The purpose of GEDCOM is to simplify the exchange of computerized historical and genealogical information. GEDCOM files are created in ASCII (text) format with special fields containing family information at the beginning of each line. The most common 
fields contain personal (name, birth date and place, death date and place) and family (links to spouse and children and links to parents and sibs) information. In some cases data contain more detailed information (occupation, title, religion, cause of death, burial place, special comments). It is worth to notice that in most cases only $7-15 \%$ of persons listed in GEDCOM files have exact dates of births and deaths as well as dates of birth and death for the parents. Thus, only small part of this information could be used for scientific analysis.

Listed below there are the most important sources of computerized genealogical data.

\subsection{Computerized Genealogical Data on CD-ROMs}

\subsubsection{Peerage CD - the Peers and Royal families of Europe}

This CD-ROM provides demographic information on 33,497 individuals (19,380 males and 13,667 females) and 18,125 marriages. The database was compiled by John Bloore, based on a test file provided with the genealogical program PEDIGREE that contained about 250 individuals, ancestors of the present Queen of England. As the program grew in size, a database was first created for the ancestors of the Prince of Wales $(5,499$ individuals) and was then expanded to include the lineages of the hereditary British peers. The database, alphabetically registered, now spans the Dukes and Earls of Abercorn to the Barons of Willoughby de Broke. Because of extensive connections between the British peerage and aristocratic families in the rest of Europe, about 15\% of the entries refer to individuals outside the UK, mostly in Germany and France.

As for data quality, special notes (see below) from the database author (John Bloore) should be taken into account before using the Peerage CD data in longevity studies.

\section{Authorised distributors:}

1. Mr. Ron City, 4 Bradwell Road, Netherton, Peterborough, PE3 9PR

2. S \& N Genealogy Supplies, Greenacres, Salisbury Rd, Chilmark, SP3 5AH

\section{General notes from the database author (Mr. John Bloore):}

1. "These databases are supplied on an "as is" basis and although every effort has been made to ensure accuracy, this cannot be guaranteed 100 percent. The author is constantly updating the information to correct errors where found, fill in details for incomplete records and to cross check information with other sources".

2. "It should also be realised that this database will never be complete. To make it so would be a job of the magnitude of the IGI [The IGI (International Genealogical Index) is an index of all temple ordinances performed by Latter-day Saints (Mormons) on behalf of deceased persons and gathers together all the parish records into one central source]! Although in most cases, I have attempted to include all known children (and their spouses), there are many instances where this has not been done and only the direct ancestors included to link". 
The genealogical data are based primarily on the following sources: $[80,99,120,121$, $165,177]$.

This data set was used in the study of human longevity and reproductive success [176]. For critical review of that study and the dataset see [61].

\subsubsection{World Family Tree Archives CDs}

The most important source of data on familial longevity is the so-called World Family Archives data set. The World Family Archives is a collection of computerized genealogies distributed on CDs (currently more than 30 volumes) by Brøderbund Software, Inc. - a company that also distributes Family Tree Maker genealogical software.

Broderbund Software initiated the World Family Tree Project after years of requests from Family Tree Maker customers who wanted a way to share their family information with each other. Thanks to the thousands of contributors to the World Family Tree, it has become one of the largest collections of family trees in the world -- and the largest one available on CD-ROM. The World Family Tree Archives CDs contain over 50 million names and 75,000 family trees.

World Family Tree CDs contain family trees dating from pre-1600 to present, first families of the United States and trees containing individuals from all over the world, complete with event dates and family links where known. These trees contain first and last names, dates of birth, marriage, and death, and names and relationships of family members These CDs exclude information about living individuals except for their name, gender, and family links. All pedigrees can be exported as GEDCOM files.

Some trees also contain source notes and biographical information. You can view this family information in Ancestor trees, Descendant trees, Outline Descendant trees, Outline Direct Descendant trees, Kinship reports, calendars, and an unlimited number of customizable reports.

To view the information in the World Family Tree, one of the following programs is necessary:

- Family Tree Maker for Windows (diskette), version 3.0 or later;

- Family Tree Maker for Windows (CD-ROM), version 3.0 or later;

- Family Tree Maker Deluxe Edition II for Windows, version 3.01 or later;

- Family Tree Maker Deluxe Edition III or later for Windows, version 4.0 or later;

- Family Tree Maker Deluxe Edition II for Power Macintosh, version 3.02 or later;

- The Family Archive Viewer.

The difference between World Family Tree Archives CDs and the information obtained using the Church of Jesus Christ of Latter-day Saints Ancestral File:

The LDS Church (Mormon Church) also collects family trees for inclusion in its "Ancestral File." This file contains approximately 15 million individuals and can be accessed at the Family History Centers of the LDS Church.

The World Family Tree differs from the Ancestral File in the following key ways: 
-Access from home -- the World Family Tree archives could be accessed from the office or home computer;

-More information on living individuals -- In the World Family Tree, the names, genders, and family links of living individuals is published. In the Ancestral File, only information about living individuals who are members of the LDS Church can be accessed. The names of non-LDS living individuals are replaced with the word "Living," and no one can access any information about these individuals.

More detailed information on the World Family Tree Project could be obtained at the Family Tree Maker Web site: http://www.familytreemaker.com.

By now the following 32 CDs are available:

a. World Family Tree: Vol. 1-2, pre-1600 to present:

World Family Tree Volumes 1-2 contain approximately 6,000 family trees contributed by Family Tree Maker customers and other family history enthusiasts. Nearly 3 million individuals are named, complete with event dates and family links where known.

b. World Family Tree: Vol. 3, pre-1600 to present:

This CD contains 6,664 family trees contributed by Family Tree Maker customers and other family history enthusiasts. Over 3 million individuals are named, complete with event dates and family links where known.

c. World Family Tree: Vol. 4-7, 9-12 pre-1600 to present:

Each of these CDs contains over 4,000 family trees. Nearly 3 million individuals in each CD are named, complete with event dates and family links where known.

d. World Family Tree: Vol. 8, pre-1600 to present:

This CD contains nearly 4,000 actual family trees. A highlight of this CD is that $18 \%$ of these trees have been submitted by Family Tree Maker customers from the United Kingdom. Overall, 3 million individuals are named, complete with event dates and family links where known.

e. World Family Tree: Vol. 13, pre-1600 to present:

This CD contains over 3,700 family trees. Nearly 3 million individuals are named, complete with event dates and family links where known.

f. World Family Tree: Vol. 14, pre-1600 to present:

This CD contains approximately 3,400 actual family trees. Nearly 2.5 million individuals are named, complete with event dates and family links where known.

g. World Family Tree: Vol. 15, pre-1600 to present:

This CD contains approximately 3,600 actual family trees. Nearly 3 million individuals are named, complete with event dates and family links where known.

h. World Family Tree Volume 16, pre-1600 to present:

This CD contains approximately 2,500 actual family trees. More than 2 million individuals are named, complete with event dates and family links where known.

i. World Family Tree Volumes 17-19, pre-1600 to present: 
These CDs contain approximately 2,300 actual family trees. Approximately 2 million individuals are named, complete with event dates and family links where known.

j. World Family Tree Volumes 20, pre-1600 to present:

This CD contains 2,700 actual family trees contributed by Family Tree Maker customers and other family history enthusiasts. Nearly 1.5 million individuals are named, complete with event dates and family links where known. Some records contain additional source notes and biographical information.

k. World Family Tree Volumes 21, pre-1600 to present:

This CD contains approximately 2,500 actual family trees contributed by Family Tree Maker customers and other family history enthusiasts. Approximately 2 million individuals are named, complete with event dates and family links where known.

l. World Family Tree Volumes 22, pre-1600 to present:

This CD contains more than 3,000 actual family trees contributed by Family Tree Maker customers and other family history enthusiasts. More than 2.5 million individuals are named, complete with event dates and family links where known.

m. World Family Tree Volumes 23, pre-1600 to present:

This CD contains more than 3,400 actual family trees contributed by Family Tree Maker customers and other family history enthusiasts. More than 2.3 million individuals are named, complete with event dates and family links where known.

n. World Family Tree Volumes 24, pre-1600 to present:

This CD contains more than 2,800 actual family trees contributed by Family Tree Maker customers and other family history enthusiasts. More than 2 million individuals are named, complete with event dates and family links where known.

o. World Family Tree Volumes 25, pre-1600 to present:

This CD contains more than 3,200 actual family trees contributed by Family Tree Maker customers and other family history enthusiasts. More than 1.8 million individuals are named, complete with event dates and family links where known.

p. World Family Tree Volumes 26, pre-1600 to present:

This CD contains more than 2,300 actual family trees contributed by Family Tree Maker customers and other family history enthusiasts. More than 1.5 million individuals are named, complete with event dates and family links where known.

q. World Family Tree Volumes 27, pre-1600 to present:

This CD contains more than 3,000 actual family trees contributed by Family Tree Maker customers and other family history enthusiasts. More than 1.8 million individuals are named, complete with event dates and family links where known.

r. World Family Tree Volumes 28, pre-1600 to present:

This CD contains more than 3,000 actual family trees contributed by Family Tree Maker customers and other family history enthusiasts. More than 1.9 million individuals are named, complete with event dates and family links where known.

s. World Family Tree Volumes 29, pre-1600 to present: 
This CD contains more than 1,630 actual family trees contributed by Family Tree Maker customers and other family history enthusiasts. More than 950,000 individuals are named, complete with event dates and family links where known.

t. World Family Tree Volumes 30, pre-1600 to present:

This 2-CD set contains 1,612 actual family trees contributed by Family Tree Maker customers and other family history enthusiasts. Approximately 1.1 million individuals are named, complete with event dates and family links where known.

u. World Family Tree Volumes 31, pre-1600 to present:

This 2-CD set contains 872 actual family trees contributed by Family Tree Maker customers and other family history enthusiasts. Approximately 1.2 million individuals are named, complete with event dates and family links where known.

v. World Family Tree Volumes 32, pre-1600 to present:

This 2-CD set contains 863 actual family trees contributed by Family Tree Maker customers and other family history enthusiasts. Approximately 1.1 million individuals are named, complete with event dates and family links where known.

w. World Family Tree: Family Albums, Volume 1:

This is the first in a series of special-edition World Family Tree CDs that contain considerably larger family trees than most other World Family Tree volumes. It contains sixty-five actual family trees contributed by Family Tree Maker customers and other family history enthusiasts. More than 100,000 individuals are named, complete with event dates and family links where known. The family trees included on this CD contain an average of 1,500 individuals -- twice as many as any previous volume of the World Family Tree. The vast majority of the trees contain photographs and other scrapbook items to add even more value to your Family File.

$x$. World Family Tree, European Origins Volume E1:

This World Family Tree European Origins CD features nearly 1,000 actual family trees with European-born ancestors. The trees on this CD have been selected from World Family Tree Volumes 1-12. Over 1.3 million individuals are named, complete with event dates and family links where known.

A significant portion of the individuals in each tree have event locations from England, Germany, Austria, France, Italy and/or other European countries. Some records contain additional source notes and biographical information.

\subsubsection{Family Pedigrees Series of CDs}

This series of CDs is also distributed by the Broderbund Software, Inc. (http://www.familytreemaker.com)

a. Family Pedigrees: United Ancestries, 1500-1990. Family Archive CD 100 This CD contains approximately 750,000 records, representing all the pedigrees and family group sheets prepared by United Ancestries, Inc., and its predecessors over a 30 year period. 
These records were chiefly prepared by professional researchers for their clients and then linked into a single database. Most birth dates fall before 1850, and some select records date from before 1500. Many of the Royal lines of Europe are included.

This CD contains individual's name and sex, genealogical links between individuals that could be export into Family Tree Maker and other GEDCOM-compatible genealogy programs

\section{b. Family Pedigrees: Everton's Computerized Family File, Volume 1, 1400s-Present. Family Archive CD 12}

Family group sheets, such as those collected in this Family Archive, are among the most useful types of records because they compile information on entire families. Unlike previous publication of Everton's Computerized Family File, which included just a name index, this Family Archive includes an index as well as images of the actual family group sheets. Combined, these family group sheets provide information on approximately 389,000 individuals from all fifty United States and around the world (including Canada, England, Germany, Denmark, the Netherlands, Norway, Prussia, Scotland, Sweden, and Switzerland).

c. Family Pedigrees: Everton Publishers, 1500-1990. Family Archive CD 15. This CD contains approximately 100,000 family groupings from Everton's Family File 1 $\& 2$ and "Roots" Cellar Vol. 1, providing information on about 1,000,000 individuals. Most of these groupings are from the United States and Europe, but some are from Latin America, Canada, the Pacific Islands, and Asia.

d. Family Pedigrees: GENTECH95 \& ARI, 1500-1989. Family Archive CD 108. This CD is a linked-relationship genealogy database containing 177,859 individual records from 103 GEDCOM files. The files were contributed to GENTECH, Inc. by family historians attending the GENTECH95 Conference, and compiled into a linked database by Automated Research, Inc. Each one of the GEDCOM files includes documentation (source notes), which add to the reliability of the data. Such documentation, while highly desirable, is uncommon among other linked genealogy databases.

\subsubsection{Acadian and French-Canadian genealogies CD}

This CD has been developed and distributed by Canadian genealogist Yvon Cyr. It contains about 200 GEDCOM files on over half million names for descendants of first French Canadians and Acadians. This CD is available for purchase (http://www.acadian.org).

\subsubsection{The Genealogical Registry and Database of Mennonite Ancestry CD-ROM Project (GRANDMA)}

GRANDMA is a project of the California Mennonite Historical Society's Genealogy Project Committee. Distributed on CD-ROM, the new volume 2 CD of the database contains 267,864 names of persons whose ancestral lines can be traced to Mennonite communities in Poland and Russia. Volume 2 is now available for purchase. For more 
information contact: California Mennonite Historical Society, 4824 E.Butler, Fresno CA 93727.

\subsubsection{The Nobility of Greater Poland (Teki Dworzaczka CD)}

This CD contains historical and genealogical sources on the nobility of Greater Poland in the 15th to 20th centuries. In particular, it contains all the unpublished research on the nobility of the Poznan / Posen region of Poland by the eminent Polish genealogist and historian- Wlodimierz Dworzaczek. His 1957 publication Genealogia established him as one of the "Dean" of Polish genealogical research. This CD comprises:

- 193,691 notes from 15th to 18 th castle and court records $\bullet 61,957$ notes from 16 th to 19th Roman Catholic \& Protestant parish church records. $\bullet 11,855$ notes of obituaries from Dziennik Poznanski $\bullet 1,026$ notes from other 18 th century newspapers (notices of lands sales and marriages) $\bullet 252$ extracts of wills $\bullet$ Pedigrees constructed from the Poznan, Pyzdry, Walz, Wschowa and Piotrków tribunal records $\bullet 12,000$ pages from the unfinished armorial Historical and Genealogical Materials for the History of Grander Property in Greater Poland.

- Gedcom Database. This database contains data on over 50,500 people including their family relationships, the coats-of-arms (herb.) used by the family, property held, their occupation or office, the years in the position and the source. Users can also import the data into their favorite genealogy programs, which have multilingual support. This CD is distributed by GenQuest company.

\subsubsection{The Nobility of the Roman Empire and Other European Nobility}

This CD contains information for 110,000 individuals who comprised the nobility and upper aristocracy (Emperors, German Emperors, Kings of subcounties, Electors, Dukes, Archdukes, Grand Dukes, Dukes, Princes, Marquis, Land Counts, Counts, the Patriarchs of Aquileja, Archbishops, Bishops, Abbots and Abbesses or the children of such) of the Holy Roman Empire and its successor states. Information supplied for the individuals include: length of office, predecessors, successors, names of parents with links to their information, date and place of birth, death and cohabitation with wives, concubines, etc., and children from each union. Each individual record is referenced with sources. The $\mathrm{CD}$ is searchable by office, person, or a combination of names and places. The genealogical data, however, are intentionally protected against exporting from the CD. This CD is also distributed by GenQuest company.

\subsection{Genealogy (GEDCOM) files available on the Internet}

Some genealogical data could be downloaded from various ftp sites on the Internet. There are several anonymous ftp sites (available for public use) which contain genealogy files (in GEDCOM format). The most important of them are:

1. Germans in Russia ftp site: pixel.cs.vt.edu.

2. Genealogy page: ftp.cac.psu.edu. 


\section{Genealogy Online: ftp.genealogy.org}

The computerized genealogical data listed in this Chapter could be accessed or purchased without any restrictions. We list here the most important sources that contain large collections of files in GEDCOM format giving the opportunity to extract data on family longevity for further analyses. We do not present here sources with small number of genealogy files or genealogy data that are not presented in GEDCOM format. It is also important while using these data to follow copyright rules established by each particular company, organization or person selling or distributing genealogical data.

\section{Published genealogical and family history data}

\subsection{Genealogical books}

Books on royal and noble genealogies.

One of the best sources of data available is the famous German edition of the "Genealogisches Handbuch des Adels" - the most reliable and complete data source on European royal and nobility families. This edition is known world-wide as 'Gotha Almanac' ('Old Gotha' published in Gotha before the Second World War, and New Gotha' published in Marburg since 1951). Each volume contains about 2,000 genealogical records appropriate for analysis, with more than 100 volumes of this edition already published. Thus, more than 200,000 genealogical records are available from this data source.

In particular, this edition consists of 4 types of volumes:

Data for royal and prince families are published in Genealogisches Handbuch der Furstlichen Hauser [78].

Data on count (earl) nobility families are published in Genealogisches Handbuch der Graflichen Hauser [76].

Data on baronial nobility families are published in Genealogisches Handbuch der Freiherrlinhen Hauser [77].

Data on gentry (nontitled noble) families are published in Genealogisches Handbuch der Adeligen Hauser [75].

Other genealogical books with particularly reliable, complete and accurate data on familial longevity for noble families include: $[7,18,26,27,34,56,87,90,102,108,109$, $115,116,123,125,146,147,150,152-155,161,164,166,167,178,180,181]$.

\subsection{Images of Genealogical Books on CDs}

Thanks to tremendous progress in computer technology many hundreds of genealogical books with detailed information on familial longevity became available now for low price in the form of image files on CDs. The most complete set of these books is available in the Broderbund Family Archive Collection described below. 


\subsubsection{Broderbund Family Archive Collection}

Broderbund Software Inc. (Banner Blue Division) initiated a large project to make images of dozens of genealogical publications (including many rare local periodical almanacs and bulletins). Listed below are the most interesting Family Archive CDs:

a. Early Settlers of New York State, 1760-1942. Family Archive CD 183

This Family Archive contains images of the pages from the following two volume set: "Early Settlers of New York State - Their Ancestors and Descendants", Volumes I and II. These books are comprised of articles that originally appeared in the periodical Early Settlers of New York State - Their Ancestors and Descendants. Edited by New York genealogist Janet Foley, its purpose was to collect, publish, and preserve church records, tombstone inscriptions, and family records, first from western New York, then from all of New York State. Referencing over 97,000 people who lived between 1760 and 1942, this collection provides little-known but first-rate source material that is essential to any researcher whose family research involves early New York State. This $\mathrm{CD}$ contains family genealogies, obituaries, Bible records, cemetery records, marriage records, church records, and death records.

\section{b. Family History: 217 Genealogy Books. Family Archive CD 113}

This CD contains the full text from 217 actual book titles, divided into the following subjects:

•Autobiography; •Biography; $\bullet$ Compendium; • Family; History; $\bullet$ Hispanic; $\bullet$ Local Histories; •Miscellaneous; $\bullet$ Native American

All sources have been preserved as originally published. The wide coverage of the CD emphasizes New England and the Eastern Seaboard. The Compendium section includes corrected versions of Virkus: Abridged Compendium of American Genealogy (Volume 1), and Savage: Genealogical Dictionary of the First Settlers of New England (Volumes 1-4).

\section{c. Family History: Colonial Genealogies \#1, 1607-1920. Family Archive CD 189}

This Family Archive contains images of the pages from all seven volumes of Colonial Families of the United States of America. Originally published by the Genealogical Publishing Company, these volumes contain information about approximately 142,000 individuals. Compiled over thirteen years, they include only those families who trace their ancestry back to the Colonial Period (1607-1775). Ranging from three to twenty scanned pages, each family history article gives the British or European pedigree of the colonial ancestor, followed by a listing of the individual's descendants up to the time of the article's writing. For your convenience and to make this important reference fully accessible, Broderbund has provided an electronic name index that allows customers to search for their ancestors.

\section{d. Family History: Connecticut Genealogies \#1, 1600s-1800s. Family Archive CD 179}

This Family Archive contains images of the pages of the three volume set Genealogies of Connecticut Families, composed of a collection of articles that were 
originally published in The New England Historical and Genealogical Register, and the three volume set Families of Ancient New Haven, compiled by American genealogist Donald Lines Jacobus. This Family Archive includes genealogies of almost every founding family of Connecticut as well as the complete ancestry and relationships of the 35,000 residents of 18th-century New Haven. Referencing over 127,000 people who lived between the 1600s and 1800s, this collection is essential to any genealogist whose family research involves Connecticut history. The materials cover the entire state, and even include information on some families whose ancestry is associated with other areas, largely Massachusetts, New York, Vermont, and the Midwest.

\section{e. Family History: English Origins of New England Families, 1500s-1800s. Family} Archive CD 181

This Family Archive contains images of the pages from the Genealogical Publishing Company's books entitled English Origins of New England Families, which trace family histories back to their English roots, some as far back as the 11th century. Included on this Family Archive are some of the most sought-after immigrant-origin articles published in The New England Historical and Genealogical Register. These articles will be of interest to almost all Americans with colonial heritage. This Family Archive references the names of more than 143,000 individuals. A sizable number of articles provide information on clusters of nearly-related immigrants or on all settlers with a given surname. Other notable inclusions are articles covering over 50 of the 125 New England immigrants of royal descent and those dealing with Mayflower passengers, colony founders, and clergymen. For convenience and easy searching, Broderbund has provided an alphabetical name index for this $\mathrm{CD}$.

\section{f. Family History: Genealogies of Long Island Families, 1600s-1800s. Family Archive CD 173}

This CD contains images of both volumes of Genealogies of Long Island Families, as well as one volume of Long Island Source Records. These books are comprised of articles originally appearing in The New York Genealogical and Biographical Record, one of the foremost publishers of Long Island genealogies. The three volumes, originally published by Genealogical Publishing Company, contain references to approximately 60,000 individuals from the present-day Suffolk, Kings, and Queens counties and represents one of the largest existing collections of Long Island genealogies and records. For convenience and easy searching, an alphabetical name index of all three volumes is included on the CD. The information available for each individual varies, depending on the original source article, but the records include genealogies, censuses, newspaper notices, town records (including deaths and marriages in some cases), Bible and family records, wills, and deeds. Some genealogies go so far as to establish the English or Dutch origins of a family.

g. Family History: Kentucky Genealogies \#1, 1700s-1800s. Family Archive CD 185

This Family Archive contains images of the pages from the following three books: Genealogies of Kentucky Families, Volumes I-III. These books contain family history articles collected from The Filson Club History Quarterly as well as articles from The Register of the Kentucky Historical Society, published between 1903 and 1965. The latter 
set of articles includes every Bible record and genealogical fragment published in the register. Referencing approximately 51,000 individuals and covering the entire state of Kentucky, the majority of the records included in this Family Archive are from the 1700s and 1800s. For convenience and easy searching, an alphabetical name index is included on the CD.

\section{h. Family History: Massachusetts and Maine Genealogies, 1650s-1930s. Family Archive CD 194}

This Family Archive contains images of the pages from Cape Cod Library of Local History and Genealogy and Massachusetts and Maine Families. Originally published by the Genealogical Publishing Company, these volumes contain information about approximately 77,000 individuals. Since relatively few Cape Cod records have survived, the 108 histories and essays collected in Cape Cod Library of Local History and Genealogy are valuable resources. They can provide a better understanding of the period in which the family ancestors lived. Massachusetts and Maine Families documents the complete ancestry of Walter Goodwin Davis. Almost anyone with considerable New England ancestry will descend from one or more of the 180 families included in this Family Archive. For your convenience, Broderbund has provided an electronic name index that allows you to search for the family ancestors quickly and easily.

i. Family History: New England Families \#1, 1600s-1800s. Family Archive CD 117

This Family Archive contains images of the pages of 13 books covering New England family histories and genealogies spanning the 1600s to the 1800 s. The books reference approximately 140,000 names. This CD can save you research time by telling you about an individual with requested ancestor's name who lived in New England during the 17th, 18th, and 19th centuries. Please note that some of the individuals included on the CD may not have lived in New England in this time period, but were mentioned in the genealogy of someone who did. For convenience and easy searching, an electronic index of all 13 books is included on this CD.

\section{j. Family History: New Jersey Genealogies \#1, 1600s-1800s. Family Archive CD 182}

This Family Archive contains images of the pages from the following two volume set: Genealogies of New Jersey Families, originally published by Genealogical Publishing Company. These books are comprised of family history articles that originally appeared in the Genealogical Society of New Jersey's journal, Genealogical Magazine of New Jersey. Begun in 1925 to promote scholarly interest in New Jersey families, the magazine continues to be a primary vehicle for New Jersey source material. Referencing over 38,000 people who lived between the early 1600s and 1800s, this collection is essential to any genealogist whose family research involves New Jersey history. The materials cover the entire state of New Jersey and include all material and Bible records published in the Magazine from the first issue through the end of Volume 65.

For the most part, this collection includes genealogies, cemetery records, church records, and family Bible records. These records may provide information on the dates and locations of important family events, as well as the names of the participants, witnesses, or other family members. 


\section{k. Family History: Pennsylvania Genealogies \#1, pre-1600 to 1900s. Family Archive CD 163}

This CD contains images of the pages of all three volumes of Genealogies of Pennsylvania Families from The Pennsylvania Genealogical Magazine, as well as one volume of Genealogies of Pennsylvania Families from The Pennsylvania Magazine of History and Biography. The four volumes, originally published by the Genealogical Publishing Company, contain several hundred family history articles and Bible records, and reference approximately 62,000 individuals from Pennsylvania as well as the Delaware Valley. The articles from these four volumes touch on families of English, Welsh, Scotch-Irish, German, Dutch, and French origins, while the Bible records dwell on hundreds of additional families, many of them inter-related.

\section{l. Family History: Rhode Island Genealogies \#1, 1600s-1800s. Family Archive CD} 180

This Family Archive contains images of the pages from the following two books: Genealogies of Rhode Island Families, Volume I and Genealogies of Rhode Island Families, Volume II. Originally published by the Genealogical Publishing Company, these books contain family history articles on Rhode Island families published in The New England Historical and Genealogical Register. This collection contains some of the best genealogical articles pertaining to Rhode Island of the past 140 years. An interesting feature of this Family Archive is that it includes source records from at least fifteen early Rhode Island towns. Referencing approximately 46,000 individuals, the majority of the records included in this Family Archive are from the late 1600s to the late 1800s. For convenience and ease of searching, an alphabetical name index of both volumes is included on the CD.

\section{m. Family History: Virginia Genealogies \#1, pre-1600 to 1900s. Family Archive CD 162}

This CD contains all five volumes of Genealogies of Virginia Families from The Virginia Magazine of History and Biography, originally published by the Genealogical Publishing Company, Inc. The family histories in these articles were compiled from eighty-four years' worth of family history articles. These articles reference approximately 65,000 individuals from all parts of Virginia. Most articles trace lines of descent through seven or eight generations, covering three or four centuries.

n. Family History: Virginia Genealogies \#2, 1600s-1800s. Family Archive CD 186

This Family Archive contains images of all five volumes of Genealogies of Virginia Families, consisting of family history articles originally published in The William and Mary College Quarterly Historical Magazine between 1892 and 1942. It also includes images of the single volume Virginia Gleanings in England, which includes articles first published in The Virginia Magazine of History and Biography between 1903 and 1926. These particular records should especially be of interest to researchers focused on the individuals with ancestry in early Virginia since they often show the English connections of colonial Virginians. Both of these books were originally published by the Genealogical Publishing Company. These articles reference over 113,000 individuals from the entire 
state of Virginia. While most of the materials date from the 1600 s to the 1800 s, a small percentage date from before 1600 and after 1899. Now with the added convenience of a name index that spans all of the volumes, this compilation is essential to any Virginia researcher's library. For customers' searching convenience, Broderbund has provided an electronic name index that spans the information from all of the collected articles. This collection contains genealogies, newspaper notices, town records (including deaths and marriages in some cases), Bible and family records, wills, and deeds.

\section{o. Family History: Virginia Genealogies \#3, 1600s-1800s. Family Archive CD 187}

This Family Archive contains all four volumes of Genealogies of Virginia Families from Tyler's Quarterly Historical and Genealogical Magazine and the complete set of Virginia Colonial Abstracts originally published by the Genealogical Publishing Company. Genealogies of Virginia Families consists of over 350 family history articles originally published in Tyler's Quarterly Historical and Genealogical Magazine between 1919 and 1952. Virginia Colonial Abstracts were originally published in thirty-four paperback volumes between 1937 and 1949. Each page of Genealogies of Virginia Families and Virginia Colonial Abstracts is accurately reproduced on this Family Archive so you can see not only the full text of the articles, but also the accompanying illustrations. These articles reference over 130,000 individuals from the entire state of Virginia. For customers' searching convenience, Broderbund has provided an electronic name index that spans all of the volumes.

\section{p. Genealogies of Mayflower Families, 1500s-1800s. Family Archive CD 171}

This archive CD contains images of the pages of Genealogies of Mayflower Families, Volumes I-III and Mayflower Source Records originally published by Genealogical Publishing Company. The volumes include a wide variety of resources pertaining to the Mayflower families which settled the southern areas of Massachusetts as well as their descendants. The records vary greatly in their content, but may provide birth, death, and lineage information in addition to baptismal, marriage, and probate records and cemetery inscriptions. The records mention approximately 111,000 individuals and are indispensable to anyone interested in researching the Mayflower families. For convenience and easy searching, an alphabetical name index of all four books is included on the CD.

q. Genealogical Records: The Complete Mayflower Descendant and Other Sources, 1600s-1800s. Family Archive CD 203

The Mayflower passengers are among the most celebrated immigrants in American history. This Family Archive contains images of the pages from the following four texts: The Mayflower Descendant, Volumes 1-46 (including a comprehensive index set for Volumes 1-34); Mayflower Passengers, 1620; Middleborough, Massachusetts Vital Records, Volumes 1-2; and Pilgrim Notes and Queries, Volumes 1-5. This Family Archive is the only electronic publication of the entire forty-six volumes of The Mayflower Descendant authorized by the Massachusetts Society of Mayflower Descendants. Combined, these four works reference the names of approximately 200,000 individuals. While the majority of the records date from the 1600 s through the $1800 \mathrm{~s}$, a number of references date back as far as the 1400s and some date well into the first half 
of the 1900s. For customers' searching convenience, Broderbund has provided an electronic name index that spans the information from all of the collected works.

\section{r. Genealogical Records: The Ontario Register, 1780s-1870s. Family Archive CD} 204

This extensive collection of genealogical records, which includes vital records as well as family histories, contains a wealth of information about residents of Canada and their descendants. This Family Archive contains images of the pages from the following texts: -Death Notices of Ontario; •Directory of the Province of Ontario, 1857 with a Gazeteer; $\bullet$ The Loyalists in Ontario: The Sons and Daughters of the American Loyalists of Upper Canada; •Marriage Bonds of Ontario, 1803-1834; •Marriage Notices of Ontario; -The Old United Empire Loyalists List; • Ontarian Families: Genealogies of United Empire Loyalists and other Pioneer Families of Upper Canada, Volumes 1 and 2; - Ontario Marriage Notices; •The Ontario Register, Volumes 1-8.

While most of the 244,000 individuals listed are from Canada, some are from the United States. For customers' searching convenience, Broderbund has provided an electronic name index that spans the information from all of the collected works.

\section{Conclusion and Suggestions for Future Work}

Information presented in this review demonstrates that an enormous amount of data on familial longevity is available now for researchers and even more data became available since our first report on this topic [60]. Millions of genealogical records are already computerized and could be potentially used for the study of the familial aggregation of human longevity. Most of these genealogies are a product of family reconstitution, carried out both by professional genealogists and by family members wishing to trace their ancestry back to the founder who brought their surname to America or even to their European family roots. The compilers of genealogies aided this timeconsuming task with the many different sources: genealogical libraries, LDS (Mormon) church family history centers, genealogical search engines available on Internet, computer CDs with census, marriage, land, probate records and many other resources for genealogical research. The potential of the existing data resources is understated and the data resources are underutilized. We hope that this review of data resources will stimulate further large-scale studies on the familial clustering of human longevity.

However, the computerized data require preliminary treatment including their transformation into relational database and critical review. It is important to study these data for their quality, accuracy and completeness before use in the longevity studies.

The most complete and reliable data on familial longevity (data on European royal and noble families) are computerized only partially by now. We hope that this work will be completed, and the database will become available for the benefit of other researchers.

Data resources on familial longevity developed for research purposes by other investigators are still not in the public domain and sometimes are even lost (for example, the Baltimore Longevity Study archive collected by Dr. Raymond Pearl and Dr. Edmund 
Murphy as well as the twin data from the Mormon Genealogy Database collected by Dr. Grace Wyshak). Therefore it is important to save the existing databases now, otherwise they may be lost irreversibly after the death of principal investigator (the case of Dr. Eva Jalavisto, for example). Thus, special efforts should be done to save existing databases and archives from longevity studies.

The data resources for the long-lived persons and their families are particularly interesting and promising for future studies of familial aggregation of human longevity. Unfortunately, most studies of exceptional longevity are concentrated on centenarians themselves and less attention is paid to the reconstruction of the detailed genealogies for the ancestors and descendants of centenarians. Thus, a special study should be done to construct detailed genealogies for the cases of exceptional longevity and to develop a database on extreme familial longevity available for other researchers.

The data presented in this review clearly demonstrate the feasibility of large-scale wold-wide studies on familial aggregation of human longevity for millions of people including cases with extreme longevity. However, the time when the results of this study become publicly available depends on future funding opportunities for this work.

\section{Acknowledgments}

We would like to acknowledge the support from Dr. Richard Suzman, National Institute on Aging, who has encouraged us to prepare the initial version of this review. A significant improvement of the text was made thanks to further support and interest of Dr. James W. Vaupel, Director of the Max Planck Institute for Demographic Research. He provided us with unique opportunity to discuss our manuscript with the participants of the two Research Workshops "Genes, Genealogies, and Longevity" held in Belgium (Louvain-la-Neuve, October 1998) and in Germany (Rostock, May 1999). We also wish to thank Dr. James Oeppen, Ms. Amandine Cournil, Dr. Bertrand Desjardins, Dr. Michel Poulain, Dr. Bernard Jeune, Dr. Axel Skytthe, Dr. Thomas Perls, Mr. John Bloore who provided us with additional information on their data resources. We would like to acknowledge the support from the National Institute on Aging grants P20 AG12857, AG13698 and AG16138. 


\section{REFERENCES}

1. Abbott M.H., Murphy E.A., Bolling D.R., Abbey H. (1974). The familial component in longevity. A study of offspring of nonagenarians. II. Preliminary analysis of the completed study. Hopkins Med. J., 134: 1-16.

2. Abbott M.H., Abbey H., Bolling D.R., Murphy E.A. (1978). The familial component in longevity. A study of offspring of nonagenarians. III. Intrafamilial studies. Am. J. Med. Genet., 2: 105-120.

3. Agarwala, R., Biesecker, L.G., Hopkins, K.A., Francomano, C.A., Schaffer, A.A. (1998). Software for constructing and verifying pedigrees within large genealogies and an application to the Old Order Amish of Lancaster. Genome Res., 8, 3: 211-221.

4. Akisaka M., Nohara Y., Suzuki M. (1996). Family history and the frequency of human leukocyte antigen (HLA-DR) in centenarians. Nippon Ronen Igakkai Zasshi 33(3): 180-185. [Article in Japanese]

5. Allard, M. (1991). A la recherche du secret des centenaires. Le Cherche-Midi, Paris.

6. Allard, M., Vallin, J., Andrieux, J.-M., Robine, J.-M. (1996). In search of the secret of centenarians: a demographic and medical survey about centenarians in France. In:

Health and mortality among elderly populations. Caselli G. and A.D. Lopez (Eds.). 61-86 pp. Clarendon Press: Oxford, England.

7. Almanach de Gotha (1764-1942). Annuaire généalogique, diplomatique et statistique. (Translation of Gothaischer Hofkalender) J. Perthes: Gotha.

8. Alpert L., DesJardines B., Vaupel J., Perls T. (1998). Extreme longevity in two families. A report of multiple centenarians within single generations. In: Age Validation of the Extreme Old. Eds: Jeune B, Vaupel J. Odense Monographs on Population Aging 4, Odense, Odense University Press.

9. Andersen H.R., Jeune B., Olsen H., Nielsen J.B., Andersen-Ranberg K., Grandjean P. (1998). Low activity of Superoxide Dismutase and high activity of Gluthathione Reductase in erythrocytes from centenarians. Age and Ageing, 27: 643-648.

10. Andersen-Ranberg K., Vasegaard L., Jeune B. (1999). Dementia is not inevitable. A population-based study of Danish centenarians. J Gerontol Psy Sci (in press).

11. Anderton, D.L., Bean, L.L., Willigan, J.D., Mineau, G.P. (1984). Adoption of fertility limitation in an American frontier population: an analysis and simulation of socioreligious subgroups. Social Biology, 31: 140-59.

12. Anderton, D.L., Tsuya, N.O., Bean, L.L., Mineau, G.P. (1987). Intergenerational transmission of relative fertility and life course patterns. Demography, 24: 467-80.

13. Baggio G., Franceschi C., Mari D., Herskind A.M., Andersen-Ranberg K., Jeune B. (1998). Biology and Genetics of Human Longevity. Australasian Journal of Ageing, 17: 8-10.

14. Bean, L.L. (1990). The Utah Population Database: demographic and genetic convergence and divergence. In: Convergent Issues in Genetics and Demography. NY, Oxford: Oxford Univ.Press, 231-244.

15. Bean, L. L.; Mineau, G. P.(1986). The polygyny-fertility hypothesis: a re-evaluation. Population Studies, 40: 67-81

16. Bean, L.L., Anderton, D.L., Mineau, G.P., Hsueh, Y. (1987). The fertility effects of marriage patterns in a frontier American population. Historical Methods, 20: 161-71. 
17. Bean, L.L., Mineau, G.P., Anderton, D.L. (1992). High-risk childbearing: fertility and infant mortality on the American frontier. Social Science History, 16: 337-63.

18. Becke-Klüchtzner, E. (1886). Stammtafeln des Adels des GHztms Baden. BadenBaden

19. Beeton, M., Pearson, K. (1899). Data for the problem of evolution in man, II: A first study of the inheritance of longevity and the selective death rate in man. Proceedings of the Royal Society of London. 65: 290-305.

20. Beeton, M., Pearson, K. (1901). On the inheritance of the duration of life and the intensity of natural selection in man. Biometrika 1: 50-89.

21. Bideau A., Brunet G., Heyer E., Plauchu H. \& Robert, J. -M. (1992) An abnormal concentration of cases of Rendu-Osler disease in the Valserine valley of the French Jura: a genealogical and demographic study. Ann. Hum. Biol. 19, 233-247.

22. Bideau, A., Desjardins, B., Pérez Brignoli, H. (1997). Infant and child mortality in the past. Oxford, England: Clarendon Press. 312 pp.

23. Bladbjerg, E.M., Andersen-Ranberg, K., de Maat, M.P.M., Kristensen, S.R., Jeune, B., Gram, J., Jespersen, J. (1999). Longevity is independent of common variations in genes associated with cardiovascular risk. Arterioscl Thombosis (in press).

24. Bocquet-Appel, J.P., Jakobi, L. (1990). Familial transmission of longevity. Ann. Human Biol., 17: 81-95.

25. Bocquet-Appel, J.P., Jakobi, L. (1991). La transmission familiale de la longévité à Arthez d'Asson (1685-1975). Population, 46: 327-47.

26. Bode, G. (1893-1905). Urkundenbuch der Stadt Goslar. Halle : O. Hendel.

27. Borgolte, M. (1986). Die Grafen Alemanniens. Sigmaringen : J. Thorbecke.

28. Bouchard, G. (1989). Population studies and genetic epidemiology in northeast Quebec. Canadian Studies in Population, 16: 61-86.

29. Bouchard, G. (1993). Population and genetics: a new frontier for the social sciences. [Population et genetique: une nouvelle frontiere pour les sciences sociales.] Annales de Demographie Historique, 397-412.

30. Bouchard, G., Roy, R., Casgrain, B. (1985). Reconstitution Automatique de Familles. Le systéme SOREP. Vol. I, II. Dossier n.2. Centre Interuniversitaire de Recherches sur les Populations, Quebec.

31. Bouchard, G., Roy, R., Casgrain, B. (1986). From micro- to macro-reconstitution of families: the SOREP system. [De la micro a la macro-reconstitution des familles: le systeme SOREP.] Genus, 42(3-4): 33-54.

32. Bouchard, G., Roy, R., Casgrain, B., Hubert, M. (1989). Population files and database management: the BALSAC database and the INGRES/INGRID system. [Fichier de population et structures de gestion de base de donnees: le fichier-reseau BALSAC et le systeme INGRES/INGRID.] Histoire et Mesure, 4(1-2): 39-57.

33. Brand, F.N., Kiely, D.K., Kannel, W.B., Myers, R.H. (1992). Family patterns of coronary heart disease mortality: The Framingham longevity study. J. Clin. Epidemiol., 45: 169-174.

34. Brandenburg, E. (1995). Die Nachkommen Karls des Grossen. Leipzig: Verlag Degener.

35. Brändström, A., Tedebrand, L.-G. (1995). Swedish urban demography during industrialization. Report from the Demographic Data Base, No. 10, ISBN 91-7191114-6. Umeå, Sweden: Umeå University, Demographic Data Base. 333 pp. 
36. Bruunsgaard, H., Andersen-Ranberg, K., Jeune, B., Pederssen, A.N., Skinhøj, P., Pedersen, B.K. A high plasma concentration of the TNF-alfa is associated with dementia in centenarians. J Gerontol Med Sci (in press).

37. Buchanan A.V., Weiss, K.M., Schwartz, R.J., MacNaughton, N.L., McCartan, M.A., Bates, S.S. (1984). Reconstruction of genealogies from vital records: The Laredo Epidemiology Project. Comput. Biomed. Res., 17: 326-351.

38. Buchanan, A.V., Weiss, K.M., Anderson, D.E., Chakraborty, R., MacNaughton, N.L. (1985). Epidemiology of breast cancer in a Mexican-American population. $J$ Natl Cancer Inst 1985 Jun;74(6):1199-206.

39. Carmelli, D. (1982). Intrapair comparisons of total life span in twins and pairs of sibs. Hum. Biol., 54: 525-537.

40. Carmelli D., Andersen, S. (1981). A longevity study of twins in the Mormon genealogy. Prog. Clin. Biol. Res., 69 Pt.C: 187-200.

41. Charbonneau, H., Desjardins, B. (1990). To live to be a hundred in the Saint Lawrence valley before 1800. [Vivre cent ans dans la vallee du Saint-Laurent avant 1800.] Annales de Demographie Historique, 1990. 217-26 pp.

42. Christensen, K., Vaupel, J.W., Holm, N.V., Yashin, A.I. (1995). Mortality among Twins after Age 6: Fetal Origin Hypotheses versus Twin Method. British Medical Journal, 310: 432-36.

43. Christensen, K., Holm, N.V., McGue, M., Corder, L., Vaupel, J.W. (1999). A Danish population-based twin study on general health in the elderly. J. Aging and Health, 11: 49-63.

44. Cournil, A., (1999). [Evidence for a familial component of longevity. A study based on the population register of the Valserine $\left(17^{\text {th }}-19^{\text {th }}\right.$ centuries $)$.] Memoire de DEA, Université Claude Bernard, Lyon. 36p. [in french]

45. Cournil, A., Legay, J-M. and Schächter, F., (1999). Evidence for a major sex-linked effect on the inheritance of longevity. Nature, (Submitted, under review)

46. Desjardins, B. (1985). Mortality at advanced ages among the founding immigrants of New France. [La mortalite aux ages avances des immigrants fondateurs de la Nouvelle-France.] Annales de Demographie Historique, 71-83.

47. Desjardins, B. (1999). Validation of extreme longevity cases in the past: The FrenchCanadian experience. In: B.Jeune and J.W.Vaupel (eds.) Validation of Exceptional Longevity. Odense University Press, Odense Monographs on Population Aging, 6: 65-78.

48. Desjardins, B., Charbonneau H. (1990). L’héritabilité de la longévité. Population, 45(3): 603-15.

49. Desjardins, B., Bideau, A., Heyer, E., Brunet, G. (1991). Intervals between marriage and first birth in mothers and daughters. Journal of Biosocial Science, 23(1): 49-54.

50. Desjardins, B., Bideau, A., Brunet, G. (1994). Age of mother at last birth in two historical populations. Journal of Biosocial Science, 26(4): 509-16.

51. Dorsten, L.E., Hotchkiss, L., King, T.M. (1999). The effect of inbreeding on early childhood mortality: twelve generations of an Amish settlement. Demography, 36, 2: 263-271.

52. Fogel R.W. (1993). New sources and new techniques for the study of secular trends in nutritional status, health, mortality, and the process of aging. Historical Methods, 26(1): 5-43. 
53. Fogel, R.W. (1997). New findings on secular trends in nutrition and mortality: some implications for population theory. In:M.R.Rosenzweig and O.Stark (eds.), Handbook of population and family economics, Amsterdam: Elsevier Science Publishers, 43381 .

54. Fogel, R.W., Costa, D.L. (1997). A theory of technophysio evolution, with some implications for forecasting population, health care costs, and pension costs. Demography, 34: 49-66.

55. Fogel, R.W., Wimmer, L.T. (1991). Aging of Union Army men: A longitudinal study, 1830-1940. Journal of the American Statistical Association, Proceedings of the Governmental Statistical Section: 56-61.

56. Frank, K.F. (1967-1974). Standeserhebungen und Gnadenakte für das Deutsche Reich und die Österreichischen Erblande bis 1806. Selbstverlag, SchloßSenftenegg.

57. Gavrilov, L.A., Gavrilova, N.S. (1997). Parental age at conception and offspring longevity. Reviews in Clinical Gerontology, 7: 5-12.

58. Gavrilov, L.A., Gavrilova, N.S. (1997). When Fatherhood Should Stop? Science, 277: 17-18.

59. Gavrilov, L.A., Gavrilova, N.S. (1997). Human reproduction in later life: a research project. Health Care in Later Life, 2(4): 275-276.

60. Gavrilov, L.A., Gavrilova, N.S. (1998). Inventory of Data Resources on Familial Aggregation of Human Longevity That Can be Used in Secondary Analysis in Biodemography of Aging. Bethesda: National Institute on Aging. NIA Professional Service Contract \#263 SDN74858. 35p.

61. Gavrilov, L.A., Gavrilova, N.S. (1999). Is there a reproductive cost for human longevity? Journal of Anti-Aging Medicine, 1999, 2(2): 121-123.

62. Gavrilov, L.A., Gavrilova, N.S., Evdokushkina, G.N., Semyonova, V.G. et al. (1996). The Genealogy of Long-Living, Golovin Genealogical Almanac, No.1, pp.5-8. [In Russian].

63. Gavrilov, L.A., Gavrilova, N.S., Kroutko, V.N., Evdokushkina, G.N., Semyonova, V.G., Gavrilova, A.L., Lapshin, E.V., Evdokushkina, N.N., Kushnareva, Yu.E. (1997). Mutation load and human longevity. Mutation Research, 377: 61-62.

64. Gavrilov, L.A., Gavrilova, N.S., Semyonova, V.G., Evdokushkina, G.N., Kroutko, V.N., Gavrilova, A.L., Evdokushkina, N.N., Lapshin, E.V. (1997). Maternal age and offspring longevity, Proc. Russian Acad. Sci. [Doklady Akademii Nauk], 354: 569572.

65. Gavrilov, L.A., Gavrilova, N.S., Semyonova, V.G., Evdokushkina, G.N., Gavrilova, A.L., Evdokushkina, N.N., Kushnareva, Yu.E., Andreyev, A.Yu. (1997). Parental age at reproduction as a predictor of human longevity. In: $16^{\text {th }}$ Congress of the IAG [International Association of Gerontology], August 19-23, 1997. Book of Abstracts. Adelaide, 461-462.

66. Gavrilov, L.A., Gavrilova, N.S., Semyonova, V.G., Evdokushkina, G.N., Kroutko, V.N., Gavrilova, A.L., Evdokushkina, N.N., Lapshin, E.V. (1998). Evolutionary theory, mutations and human life span. Proc. Russian Acad. Sci. [Doklady Akademii Nauk], 359(3): 426-427. English translation published in Doklady Biological Sciences, 1998, 359: 159-160.

67. Gavrilov, L.A., Gavrilova, N.S., Semyonova, V.G., Evdokushkina, G.N., Kroutko, V.N., Gavrilova, A.L., Evdokushkina, N.N., Kushnareva, Yu.E. (1998). The 
regularities of inheritance of human life span: contribution of paternal and maternal longevity to the offspring life span. Proc. Russian Acad. Sci. [Doklady Akademii Nauk], 360(2): 281-283.

68. Gavrilov, L.A., Gavrilova, N.S., Evdokushkina, G.N., Semyonova, V.G. (1998). Biodemographic study of parental age effects on human longevity. Paper presented at the 1998 PAA Annual Meeting (Chicago, April 2-4, 1998). Abstract \#20595 published in: Population Association of America. 1998 Annual Meeting. Final Program and Abstracts. p.142.

69. Gavrilov, L.A., Gavrilova, N.S., Evdokushkina, G.N., Semyonova, V.G. (1998). Human longevity, spontaneous mutations and paternal age. The Gerontologist. 38(1): 8.

70. Gavrilov, L.A., Gavrilova, N.S., Evdokushkina, G.N., Semyonova, V.G. (1999). Children born to older mothers do not inherit maternal life span. In: Proceedings of the 28th Annual Meeting of the American Aging Association (AGE). June 4-8, 1999. Seattle: AGE, 22-23.

71. Gavrilova, N.S., Gavrilov, L.A., Evdokushkina, G.N., Semyonova, V.G. (1998). Mechanisms of familial transmission of human longevity: comparison of maternal and paternal contributions into offspring lifespan. Paper presented at the 1998 PAA Annual Meeting (Chicago, April 2-4, 1998). Abstract \#20596 published in: Population Association of America. 1998 Annual Meeting. Final Program and Abstracts. p.142.

72. Gavrilova, N.S., Gavrilov, L.A., Evdokushkina, G.N., Semyonova, V.G., Gavrilova, A.L., Evdokushkina, N.N., Kushnareva, Yu.E., Kroutko, V.N., Andreyev, A.Yu. (1998). Evolution, mutations and human longevity: European royal and noble families. Human Biology 70: 799-804.

73. Gavrilova, N.S., Gavrilov, L.A., Evdokushkina, G.N., Semyonova, V.G. (1998). Nonlinear transmission of human longevity from mother to daughter. The Gerontologist. 38(1): 8.

74. Gavrilova, N.S., Gavrilov, L.A., Evdokushkina, G.N., Semyonova, V.G. (1999).The future of human longevity: a more realistic approach for life expectancy forecasting. In: Proceedings of the 28th Annual Meeting of the American Aging Association (AGE). June 4-8, 1999. Seattle: AGE, 22.

75. Genealogisches Handbuch der Adeligen Hauser. (1953), vol.5. Genealogisches Handbuch des Adels. Van Hueck W. (ed.). Limburg an der Lahn: C.A.Starke Verlag. Ibid. (1955) 9, 11; Ibid. (1956) 12; Ibid. (1957) 15; Ibid. (1958) 17; Ibid. (1959) 20; Ibid. (1960) 22, 24; Ibid. (1961) 26; Ibid. (1962) 29; Ibid. (1964) 32; Ibid. (1965) 34, 36; Ibid. (1966) 38; Ibid. (1968) 41; Ibid. (1969) 45; Ibid. (1970) 46; Ibid. (1971) 49; Ibid. (1972) 52; Ibid. (1974) 57; Ibid. (1975) 60; Ibid. (1977) 64; Ibid. (1979) 71; Ibid. (1980) 73; Ibid. (1981) 76, 78; Ibid. (1983) 81; Ibid. (1984) 83; Ibid. (1985) 86, 87; Ibid. (1986) 89; Ibid. (1987) 89; Ibid. (1988) 93; Ibid. (1992) 103.

76. Genealogisches Handbuch der Graflichen Hauser. Genealogisches Handbuch des Adels. (1952), vol. 2. Van Hueck W. (ed.). Limburg an der Lahn: C.A.Starke Verlag. Ibid. (1953) 6; Ibid. (1955) 10; Ibid. (1958) 18; Ibid. (1960) 23; Ibid. (1962) 28; Ibid. (1965) 35; Ibid. (1967) 40; Ibid. (1970) 47; Ibid. (1973) 54, 55, 56; Ibid. (1976) 63; Ibid. (1979) 72; Ibid. (1983) 82; Ibid. (1991) 101; Ibid. (1993) 104, 105. 
77. Genealogisches Handbuch der Freiherrlinhen Hauser. (1952), vol.4. Genealogisches Handbuch des Adels. (1994). Van Hueck W. (ed.). Limburg an der Lahn: C.A.Starke Verlag. Ibid. (1954) 7; Ibid. (1956) 13; Ibid. (1957) 16; Ibid. (1959) 21; Ibid. (1962) 27; Ibid. (1963) 30, 31; Ibid. (1966) 37; Ibid. (1967) 39; Ibid. (1969) 44; Ibid. (1970) 48; Ibid. (1971) 51; Ibid. (1975) 59; Ibid. (1976) 62; Ibid. (1977) 65; Ibid. (1978) 68; Ibid. (1979) 69; Ibid. (1982) 79, 80; Ibid. (1986) 88; Ibid. (1992) 102; Ibid. (1994) 106, 107.

78. Genealogisches Handbuch der Furstlichen Hauser. Genealogisches Handbuch des Adels. (1951), vol.1. Van Hueck W. (ed.). Limburg an der Lahn: C.A.Starke Verlag. Ibid. (1953) 3; Ibid. (1955) 8; Ibid. (1956) 14; Ibid. (1959) 19; Ibid. (1961) 25; Ibid. (1964) 33; Ibid. (1968) 42; Ibid. (1971) 50; Ibid. (1978) 70; Ibid. (1980) 74, 75; Ibid. (1984) 85; Ibid. (1987) 90; Ibid. (1991) 100.

79. Gerdes, U., Jeune, B., Olsen, H., Andersen-Ranberg, K., Vaupel, J.W. (1999). The apolipoproteine E gene is a frailty gene, not a longevity gene. Genetic Epidemiology (in press)

80. Gibbs, V., Doubleday, H.A., De Walden, H., White, G.H. (1910-1959). The Complete Peerage of England, Scotland, Ireland, Great Britain and the United Kingdom, London: St. Catherine.

81. Hawkins, M.R., Murphy, E.A., Abbey, H. (1965). The familial component of longevity. A study of the offspring of nonagenarians. I. Methods and preliminary report. Bull. Johns Hopkins Hospital, 117: 24-36.

82. Herskind, A.M., McGue, M., Holm, N.V., Sorensen, T.I., Harvald, B., Vaupel, J.W. (1996). The heritability of human longevity: a population-based study of 2872 Danish twin pairs born 1870-1900. Hum. Genet., 97: 319-23.

83. Heyer, E. (1993) Population structure and immigration; a study of the Valserine Valley (French Jura) from the $17^{\text {th }}$ century until the present. Ann. Hum. Biol. 20, 565573.

84. Hirose, N., Arai, Y., Kawamura, M., Homma, S., Hasegawa, H., Ishida, H., Shimizu, K., Osono, Y., Takeda, S., Noji, H., Homma, A., Nakamura, Y. (1997). Nutritional status of Japanese centenarians. Nippon Ronen Igakkai Zasshi, 34: 324-30. (In Japanese).

85. Hollingsworth, T.H. (1969). Historical Demography. Ithaca, N.Y.: Cornell University Press.

86. Hostetler, J.A. (1985). History and relevance of the Hutterite population for genetic studies. Am.J.Med.Genet., 22: 453-462.

87. Huberty, M. (1976-1985). L Allemagne Dynastique. Le Perreux-sur-Marne: Giraud.

88. Igartua, J.E., Bouchard, G., Charbonneau, H., Gagan, D., Darroch, G., Gaffield, C. (1988). Historical databases: the Canadian experience for the past fifteen years. [Les bases de donnees historiques: l'experience canadienne depuis quinze ans.] Histoire Sociale/Social History, 21(42): 283-317.

89. Inagaki, T., Niimi, T., Yamamoto, T., Hashizume, Y., Ogihara, M., Mizuno, T., Inagaki, A., Kikuchi, M. (1996). Sociomedical study of centenarians in Nagoya City. Nippon Ronen Igakkai Zasshi, 33(2):84-94. [Article in Japanese]

90. Isenburg, W.K.(1953). Europäische Stammtafeln. Marburg.

91. Jalavisto, E. (1951). Inheritance of longevity according to Finnish and Swedish genealogies. Ann. Med. Intern. Fenn., 40:263-74. 
92. Jeune, B., Kannisto, V. (1997). Emergence of Centenarians and Supercentenarians. In Longevity: To the limits and beyond (Eds. Jean-Marie Robine, James W. Vaupel, Bernard Jeune, Michel Allard), Fondation Ipsen, Berlin Heidelberg: Springer Verlag.

93. Jeune, B., Vaupel, J.W., ed. (1995). Exceptional Longevity: From Prehistory to the Present. Odense Monographs on Population Aging 2. Odense University Press, 169p.

94. Jeune, B., Skytthe, A., Vaupel, J.W., (1996). The demography of centenarians in Denmark. Ugeskr Laeger, 158(51):7392-7396. [Article in Danish]

95. Jorde, L.B., Skolnick, M.H. (1983). Demographic and genetic applications of computerized record linking: the Utah Mormon genealogy. Informatique et Sciences Humaines, 14 (56-57): 105-117.

96. Kasakoff, A.B., Adams, J.W. (1995). The effect of migration on ages at vital events: a critique of family reconstitution in historical demography. Eur. J. Pop., 11: 199-242.

97. Kearl, J. R., Pope, C.L. (1986). Unobservable family and individual contributions to the distributions of income and wealth. Journal of Labor Economics, 4: 48-82.

98. Khoury, M.J., Cohen, B.H., Diamond, E.L., Chase, G.A., McKusick, V.A. (1987). Inbreeding and prereproductive mortality in the Old Order Amish. I. Genealogic epidemiology of inbreeding. Am J Epidemiol 125(3):453-461

99. Kidd, C., Williamson, D. (1994). Debrett's Peerage and Baronetage, London: Macmillan.

100. King, T.M., Beaty, T.H., Liang, K.Y. (1996). Comparison of methods for survival analysis of dependent data. Genet Epidemiol, 13(2):139-158.

101. Knodel, J.E. (1988). Demographic behavior in the past: a study of fourteen German village populations in the eighteen and nineteen centuries. New York: Cambridge University Press.

102. Köbler, G. (1990). Geschichte deutscher Territorien.

103. Kristensen, S.R., Andersen-Ranberg, K., Bathum, L., Jeune, B. (1998). Factor V Leiden and venous thrombosis in Danish centenarians. Thromb. Haemost., 80:860861.

104. Larsen, U.; Vaupel, J.W. (1993). Hutterite fecundability by age and parity: strategies for frailty modeling of event histories. Demography, 30: 81-102.

105. Le Bourg, E., Thon, B., Légaré, J., Desjardins, B., Charbonneau, H. (1993). Reproductive life of French-Canadians in the 17-18th centuries: a search for a trade-off between early fecundity and longevity. Exp. Gerontol., 28: 217-232.

106. Lee, J., Campbell, C., Wang, F. (1993). The last emperors: an introduction to the demography of the Qing (1644-1911) Imperial Lineage. In: D.S. Reher and R. Schofield (eds.), Old and new methods in historical demography. Clarendon Press: Oxford, 361-82.

107. Lee, J., Wang, F., Campbell, C. (1994). Infant and child mortality among the Qing nobility: implications for two types of positive check. Population Studies, 48: 395411.

108. Litta, P. (1840). Famiglie Celebri Italiane.Vol.6,14, Milano, 1840. Ibid. (1909). Suppl.1-3, Napoli.

109. Loringhoven, F. (1965). Europäische Stammtafeln. 2/3.Aufl. Marburg.

110. Louhija, J., Miettinen, H.E., Kontula, K., Tikkanen, M.J., Miettinen, T.A., Tilvis, R.S. (1994). Aging and genetic variation of plasma apolipoproteins. Relative loss of 
the apolipoprotein E4 phenotype in centenarians. Arterioscler Thromb., 14(7):10841089

111. Lundberg, A. (1996). Health and social consequences: linkages between parish registers and patient records as a source in social medical history. Yearbook of Population Research in Finland, 33: 306-18. Helsinki, Finland.

112. Lynch, K.A., Mineau, G.P., Anderton, D.L. (1985). Estimates of infant mortality on the Western frontier: the use of genealogical data. Historical Methods, 18: 155-64.

113. Mari, D, Maestroni, A.M (1995). Centenarians in Milan. Ann Ital.Med.Int. 10(1):46-48. (In Italian).

114. Martin, P., Poon, L.W., Kim, E., Johnson, M.A. (1996). Social and psychological resources in the oldest old. Exp.Aging Res., 22: 121-139.

115. Mast, P. (1988). Die Hohenzollern.Graz, Wien Köln.

116. Matz, K.J. (1980). Regententabellen zur Weltgeschichte. München.

117. Mayer, P.J. (1991). Inheritance of longevity evinces no secular trend among members of six New England families born 1650-1874. Am. J. Hum. Biol., 3: 4958.

118. McGue, M., Vaupel, J.W., Holm, N., Harvald B. (1993). Longevity is moderately heritable in a sample of Danish twins born 1870-1880. J. Gerontol., 48, B237B244.

119. Mineau, G.P., Anderton, D.L., Bean, L.L. (1989). Description and evaluation of linkage of the 1880 manuscript census to family genealogies with implications for Utah fertility research. Historical Methods, 22: 144-157.

120. Moncreiffe, I. (1982). Royal Highness. Ancestry of the Royal Child. London: Hamish Hamilton.

121. Morby, J.E. (1994). The Wordworth Handbook of Kings and Queens. Grasmere: Wordsworth Editors.

122. Murphy, E.A. (1978). Genetics of longevity in man. In: Schneider E. (ed.). The Genetics of Aging. NY: Plenum Press, 261-301.

123. Münster, H. (1925). Ahnenliste Palm-Münster. Görlitz.

124. Nault, F., Desjardins, B., Legare, J. (1990). Effects of reproductive behaviour on infant mortality of French-Canadians during the seventeenth and eighteenth centuries. Population Studies, 44(2): 273-85.

125. Naumann, G. (1991). Sächsische Geschichte in Daten. Berlin, Leipzig Köhler und Amelang,

126. Nozaki, H., Ashitomi, I., Higa, K., Akisaka, M., Suzuki, M (1995). Red blood cell parameters of healthy centenarians. Nippon Ronen Igakkai Zasshi; 32(7):471-477. [Article in Japanese]

127. Ober, C., Hyslop, T., Hauck, W.W. (1999). Inbreeding effects on fertility in humans: evidence for reproductive compensation. Am J Hum Genet, 64, 1:225-31.

128. Oeppen, J.E. (1998). Mortality and Marital Status in the British Peerage: 1603 1938. Paper presented at the S.S.H.A. Conference, Chicago.

129. Okamoto, K., Sasaki, R. (1995). Geographical epidemiologic studies on factors associated with centenarians in Japan. Nippon Ronen Igakkai Zasshi, 32(7):485490. [Article in Japanese] 
130. Olsen, H., Jeune, B., Andersen-Ranberg, K. (1996). Centenarians in the county of Funen. Morbidity and functional capacity]. Ugeskr Laeger, 158(51):7397-7401. [Article in Danish]

131. Paget, G. (1977). The Lineage and Ancestry of H.R.H. Prince Charles, Prince of Wales. Edinburgh: Skilton.

132. Pearl, R., Pearl R. De W. (1934). The Ancestry of the Long-Lived. Baltimore: The John Hopkins Press.

133. Perls, T.T. (1995). Demographic selection's influence upon the oldest old. J. Gerontologic Psychiatry, 28:33-56.

134. Perls, T.T. (1995). The Oldest Old. The Scientific American, 272:70-75.

135. Perls, T. (1997). Centenarians prove the compression of morbidity hypothesis, but what about the rest of us who are genetically less fortunate? Medical Hypothesis, 49: 405-407.

136. Perls, T, Alpert, L, Fretts, R. (1997). Middle aged mothers live longer. Nature, 389:133.

137. Perls T, Alpert, L, Wager, CG, Vijg, J, Kruglyak, L. (1998). Siblings of centenarians live longer. Lancet, 351:1560.

138. Perls, T.T., Bochen, K., Freeman, M., Alpert, L., Silver, M.H. (1998). The New England Centenarian Study: validity of reported age and prevalence of centenarians in an eight town sample. In: Age Validation of the Extreme Old. Eds: Jeune B, Vaupel J. Odense Monographs on Population Aging, 4, Odense, Odense University Press.

139. Perls, T.T., Bochen, K., Freeman, M., Alpert, L., Silver, M.H. (1999). Validity of reported age and centenarian prevalence in New England. Age and Ageing, 28:193197.

140. Perron, M., Veillette, S., Rainville, M., Hebert, G., Bouchard, C., Tremblay, C., Otis, J.-C. (1991). Social and spatial differentials in mortality in Saguenay (Quebec): evaluation of the use of the death register for microanalysis. [Differenciation sociale et spatiale de la mortalite au Saguenay (Quebec): validation d'un registre de deces pour des analyses a micro-echelle.] Espace, Populations, Societes, 1: 223-34.

141. Plauchu, H., Bideau, A. (1984). Epidémiologie et constitution d'un registre de population à propos d'une concentration géographique d'une maladie héréditaire rare. Population, 4-5, 765-786. [in French]

142. Poon, L.W. (1992). The Georgia Centenarian Study. Special issue of The International Journal of Aging \& Human Development, vol.34.

143. Pope, C.L. (1992). Adult mortality in America before 1900. A view from family histories. In: C.Goldin and H.Rockoff (eds.), Strategic Factors in Nineteenth Century American Economic History. A Volume to Honor Robert W. Fogel. Chicago and London: Univ. Chicago Press, 267-296.

144. Pope, C.L., Wimmer, L.T. (1998). Aging in the early 20th century. American Economic Review, 88: 217-21.

145. Poulain, M., Chambre, D., Foulon, M. (1999). Centenarian validation in Belgium. In: B.Jeune and J.W.Vaupel (eds.) Validation of Exceptional Longevity. Odense University Press, Odense Monographs on Population Aging, 6: 65-78.

146. Rall, H., Rall, M. (1986). Die Wittelsbacher.Graz, Wien, Köln. 
147. Reifenscheid, R. (1982). Die Habsburger. Graz, Wien Köln.

148. Robine J.-M., Allard M. (1997). Towards a genealogical epidemiology of longevity. In: J.-M.Robine, J.W.Vaupel, B.Jeune, M.Allard (eds.) Longevity: To the Limits and Beyond. Berlin, Heidelberg: Springer-Verlag, 121-29.

149. Robine J.-M., Allard M. (1998). The oldest human. Science, 279: 1832.

150. Rösch, S. (1977). Caroli Magni Progenies. Neustadt a.d.Aisch.

151. Samuelsson, S.M., Alfredson, B.B., Hagberg, B., Samuelsson, G., Nordbeck, B., Brun, A., Gustafson, L., Risberg, J. (1997). The Swedish Centenarian Study: a multidisciplinary study of five consecutive cohorts at the age of 100. Int J Aging Hum Dev., 45(3):223-253.

152. Schindling, A., Zigler, W. (1990). Die Kaiser der Neuzeit. München.

153. Schlösser, S. (1993). Wahl- und Krönungsakten des Mainzer ReichserzkanzlerArchivs 1486-1711. Stuttgart.

154. Schwennicke, D. (1980-1994). Europaeische Stammtafeln. Marburg: Neue Folge.

155. Schwennicke, D. (1998). Europaeische Stammtafeln. Frankfurt am Main: V.Klostermann.

156. Silver, M., Newell, K., Growdon, J., Hyman, B.T., Hedley-Whyte, E.T., Perls, T. (1998). Unraveling the mystery of cognitive changes in old age: Correlation of neuropsychological evaluation with neuropathological findings in the extreme old. International Psychogeriatrics, 10(1):25-41.

157. Skolnick, M., Bean, L.L., Dintelman, S.M., Mineau, G. (1979). A computerized family history data base system. Sociology and Social Research, 63: 506-523.

158. Skytthe, A., Hauge, G., Jeune, B. (1999). Age validation of reported centenarians before 1900 in Denmark. In: B.Jeune and J.W.Vaupel (eds.) Validation of Exceptional Longevity. Odense University Press, Odense Monographs on Population Aging, 6: 79-96.

159. Smith, J.E., Oeppen, J. (1993). Estimating number of kin in historical England using demographic microsimulation. D.S.Reher and R. Schofield (eds.). Old and New Methods in Historical Demography. Oxford: Clarendon Press, 280-317.

160. Sobel, E., Louhija, J., Sulkava, R., Davanipour, Z., Kontula, K., Miettinen, H., Tikkanen, M., Kainulainen, K., Tilvis, R. (1995). Lack of association of apolipoprotein E allele epsilon 4 with late-onset Alzheimer's disease among Finnish centenarians. Neurology, 45(5):903-907.

161. Stockmeier, M. (1964). Merian Ahnen aus zwölf Jahrhunderten. Konstanz.

162. Tedebrand, L.-G. (1994). Mortality of persons over age 80, Sweden 1750-1980. [Von der Sterblichkeit der uber 80 jahrigen, Schweden 1750-1980.] In: Erfullt leben--in Gelassenheit sterben: Geschichte und Gegenwart, edited by Arthur E. Imhof and Rita Weinknecht. Berliner Historische Studien, 19: 129-43. Berlin: Duncker und Humblot. In Ger.

163. The Italian Multicentric Study on Centenarians. (1997). Epidemiological and socioeconomic aspects of Italian centenarians. Arch.Gerontol.Geriatr., 25: 149-157.

164. Thiele, A. (1991). Erzählende genealogische Stammtafeln zur europäischen Geschichte. Frankfurt.

165. Townsend, P. (1963). Burke's Genealogical and Heraldic History of the Peerage, Baronetage and Knightage, London: Burke's Peerage. 
166. Trotter, K. (1931). Die Grafen von Scheyern, Dachau, Valley, Wittelsbach, Pfalzgrafen und Herzöge von Bayern.

167. Truhart, P. (1986). Regents of Nations, Part III/1. München etc.

168. Vaupel, J.W., Carey, J.R., Christensen, K., Johnson, T.E., Yashin, A.I., Holm, N.V., Iachine, I.A., Kannisto, V., Khazaeli, A.A., Liedo, P., Longo, V.D., Zeng, Yi, Manton, K.G., Curtsinger, J.W. (1998). Biodemographic trajectories of longevity. Science, 280(5365): 855-60.

169. Vogel, F., Motulsky, A.G. (1997). Human Genetics. Problems and Approaches. Berlin: Springer-Verlag.

170. Wang, F., Lee, J., Campbell, C. (1995). Marital fertility control among the Qing nobility: implications for two types of preventive check. Population Studies, 49, 3: 383-400.

171. Wang, Zh., Zeng, Yi, Jeune, B., Vaupel, J.W. (1998). Age validation of Han Chinese centenarians. Genus, 54(1-2) 123-41.

172. Wang, Zh., Zeng, Yi, Jeune, B., Vaupel, J.W. (1999). Age validation of Han Chinese centenarians. In: B.Jeune and J.W.Vaupel (eds.) Validation of Exceptional Longevity. Odense University Press, Odense Monographs on Population Aging, 6: 195-214.

173. Weiss, K.M., Chakraborty, R., Schull, W.J., Rossmann, D.L., Norton, S.L. (1980). The Laredo Epidemiology Project. In: J.Cairns, J.L.Lyon, M.Skolnick (eds.), Cancer Incidence in Defined Populations, Bunbury Report 4, Cold Spring Harbor Laboratories. 267-297 (with discussion).

174. Weiss, K.M., Ferrell, R.E., Hanis, C.L., Styne, P.N. (1984). Genetics and epidemiology of gallbladder disease in New World native peoples. Am J Hum Genet., 36(6):1259-78

175. Weiss, K.M., Chakraborty, R., Smouse, P.E., Buchanan, A.V., Strong, L.C. (1986). Familial aggregation of cancer in Laredo, Texas: a generally low-risk MexicanAmerican population. Genet Epidemiol., 3(2):121-43.

176. Westendorp, R.G, Kirkwood, T.B. (1998). Human longevity at the cost of reproductive success. Nature, 396(6713): 743-6

177. Whittaker's Almanac, (1996). London: Whittaker.

178. Wilberg, M. (1987). Regenten-Tabellen. Berlin: Transpress.

179. Wilmoth, J., Skytthe, A., Friou, D., Jeune, B. (1996). The oldest man ever? A case study of exceptional longevity. The Gerontologist, 36:783-8.

180. Wolf, A. (1991). Ein Süddtiroler als Wähler des römisch-deutschen Königs. Der Vinschgau.

181. Wurzbach, C. (1856/57 - 1890/91). Biographisches Lexikon des Kaiserthums Österreich. Wien: Zamarski.

182. Wyshak, G. (1978). Fertility and longevity of twins, sibs, and parents of twins. Soc. Biol., 25: 315-30.

183. Zhao, Zh. (1997). Long-term mortality patterns in Chinese history: Evidence from a recorded clan population. Population Studies, 51: 117-127.

184. Zheng, Z.X., Wang, Z.S., Zhu, H.M., Yang, J.Y., Peng, H.Y., Wang, L.X., Li J., Jiang, X.W., Yu, Y.F. (1993). Survey of 160 centenarians in Shanghai. Age Ageing, 22(1):16-19. 